\title{
Rekonsiderasi Budaya Manumbai Masyarakat Petalangan Melayu Riau Berbasis Al-Qur'an
}

\author{
Miftah Ulya \\ STAI Diniyah Pekanbaru Riau \\ e-mail: miftahulya77@gmail.com \\ Nurliana \\ STAI Diniyah Pekanbaru Riau \\ e-mail: nurlianamalay@gmail.com
}

\begin{abstract}
Manumbai is a tradition of taking honey bee that is familiar to the people of Riau Malay Petalangan. In their view there remains a facet of inner strength, a power which cannot be reached by external effort. The unseen inner strength is greater than the outer strength. Therefore, doing a job with physical strength alone will not be sufficient, without being equipped with the effort to obtain supernatural inner strength. It has been popular that "Malay is synonymous with Islam" is a slogan that has been popular among the Riau Malay community. Even so, there still seems to be a discrepancy from what was popularized in the slogan. The author found that the manumbai procession (the ceremony for taking honey bees) in the culture of the Riau Malay Petalangan community seems to contradict the prohibitions in the al-Qur'an which are contained in the QS. Al-Nisā'[4]: 171, namely' al-ghuluww "means transgressing the limit. This research uses a qualitative approach. While the method of interpretation in research uses the maudhu' $\bar{i}$ interpretation method. The stages in this research go through three stages, namely reading and tracing the literature (primary and secondary), which then analyzes the data with a descriptive analytical frame of mind, which in the end comes a conclusion. The author gives a reconsideration of the manumbai culture of the Riau Malay Petalangan community which seems to contradict the prohibition of the al-Qur'an through transformation. The desired consideration in this research is through changing the form of worship of the sialang tree which is believed to have magical powers to trust and complete belief in Allah, who is the giver and recipient of the prayers of all his servants' requests.
\end{abstract}

Keywords: Reconsideration, Manumbai, Malay Culture.

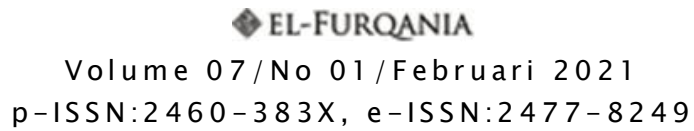


Abstrak: Telah populer bahwa "Melayu identik dengan Islam" demikian slogan yang sudah populer di kalangan masyarakat Melayu Riau. Walau demikian, masih tampak ketidakselarasan dari apa yang dipopulerkan pada slogannya tersebut. Penulis menemukan bahwa prosesi manumbai (upacara mengambil madu lebah) pada budaya masyarakat Petalangan Melayu Riau terkesan berseberangan dengan larangan dalam al-Qur'an yang termaktub pada QS. Al Nisā' [4]: 171, yaitu 'al-ghuluww" bermakna melampaui batas. Manumbai adalah tradisi menganmbil madu lebah tidak asing bagi masyarakat Petalangan Melayu Riau. Dalam pandangan mereka tetap ada suatu segi kekuatan batin, kekuatan yang tak dapat dijangkau dengan upaya lahiriah. Kekuatan batin yang ghaib itu lebih hebat daripada kekuatan lahiriah. Sebab itu melakukan suatu pekerjaan dengan kekuatan lahiriyah saja tidak akan mencukupi, tanpa dilengkapi dengan upaya memperoleh kekuatan batin yang gaib. Penelitian ini menggunakan pendekatan kualitatif. Sedangkan metode penafsiran dalam penelitian menggunakan metode tafsir maudu' $\bar{i}$. Tahapan dalam penelitian ini melalui tiga tahap, yaitu membaca dan menelusuri literatur-literatur (primer dan skunder), yang kemudian menganalisa data tersebut dengan kerangka berfikir deskriptif analitis, yang pada akhirnya diperoleh kesimpulan. Penulis memberikan rekonsiderasi terhadap budaya manumbai masyarakat Petalangan Melayu Riau yang terkesan bertentangan dengan larangan al-Qur'an melalui transformasi. Konsiderasi yang dikehendaki dalam penelitian ini adalah melalui perubahan bentuk dari pemujaan terhadap pohon sialang yang diyakini memiliki kekuatan magis kepada kepercayaan dan keyakinan sepenuhnya kepada Allah YME yang maha pemberi dan penerima doa segala pinta hamba-Nya.

Keywords : Rekonsiderasi, Manumbai, Budaya Melayu.

\section{Prolog}

Dalam masyarakat Melayu Riau mengenal dengan tingkatan adat. Tingkatan adat itu adalah " adat sebenar adat, adat yang teradat, dan adat yang diadatkan." Dari nilai dapat pula diklasifikasikan

\footnotetext{
${ }^{1}$ Adat Melayu Riau ada tingkatan yang disebut dengan 'adat sebenar adat". Maksudnya adalah bahwa prinsip adat Melayu yang tak dapat diubah-ubah. Prinsip tersebut tersimpul dalam adat bersendikan syarak. Ketentuan-ketentuan adat yang bertentangan dengan hukum syarak tidak boleh dipakai lagi, dan hukum syarak-lah yang dominan. Intinya adalah dasar adat Melayu Riau dalam hal ini menghendaki
} 
Rekonsiderasi Budaya Manumbai Masyarakat

mengenai norma, hukum dan ketentuan khusus. Dengan demikian, bila dibandingkan antara adat yang teradat dengan adat yang diadatkan terlihat dari segi keumuman berlakunya. Adat yang diadatkan bersifat umum pemakaiannnya pada seluruh tempat dan wilayah, dalam hal ini Melayu Riau, sementara adat yang teradat adalah kebiasaan pada masyarakat di suatu tempat dalam wilayah Melayu Riau, misalkan adat pada suatu kabupaten kota yang ada. ${ }^{2}$

Dalam membahas budaya Melayu Riau ${ }^{3}$ dengan berbagai aspek yang dimiliki telah mampu meningkatkan daya nalar dan karya masyarakat pendukungnya. ${ }^{4}$ Sebab dapat dikatakan bahwa kesadaran suatu masyarakat untuk mempertahankan tradisi dan budaya mereka, tidak terlepas dari seberapa berpengaruhnya dan sekuat apa

sandaran-sandarannya kepada sunnah nabi dan kitab suci al-Qur'an. Prinsip itulah yang tidak dapat diubah alih, tidak dapat dibuang, apalagi dihilangkan. Maka inilah yang kemudian disebut adat sebenar adat. Isjoni Ishaq, et al., Orang Melayu Sejarah, Sistem, Norma dan Nilai Adat, (Pekanbaru: UNRI Press, 2010), 1-2.

${ }^{2}$ Adat yang teradat merupakan konsensus bersama yang dirasakan cukup baik sebagai pedoman dalam menentukan sikap dan tindakan dalam mengahdapi setiap peristiwa yang terjadi dalam masyarakat. Konsensus ini dijadikan sebagai pegangan bersama, sehingga merupakan kebiasaan turun-temurun. Adat yang teradat juga dapat berubah ubah sesuai dengan nilai-nilai baru yang berkembang di tengah masyarakat. Husni Tamrin (ed), Agama dan Budaya, Pekanbaru: LPPM UIN Suska Riau, 2009, hal. 16.

${ }^{3}$ Orang Melayu di Nusantara di masa silam mempunyai peran yang sangat besar dalam proses asimilasi dan akulturasi yang bersentuhan dengan budaya asing atau luar di kawasan Asia Tengggra. Menurut Parsudi Suparlan dan S. Budisantoso, orang Melayu inilah sebenarnya paling awal berhubungan dengan orang asing khususunya orang-orang Asia dan Eropa yang datang ke Asia Tenggara untuk mencari bahan-bahan mentah dan rempah rempah. Persentuhan dan interaksi orang Melayu dengan budaya luar itu telah memperkaya nilai-nilai adat dan budaya Melayu. Suwarto et.al., Mengangkat Keberadaan Hak-hak Tradisional Masyarakat Adat Rumpun Melayu se-Sumatera, (Pekanbaru: Unri Press, 2006), hal. 12.

${ }^{4}$ Ciri orang Melayu dewasa ini adalah ketiga unsur budaya tersebut yakni berbahasa Melayu, beragama Islam dan beradat-istiadat Melayu. Walaupun secara historis ada semacam usaha terkonstruk dengan rapih pada budaya Melayu yang telah terpengaruh dengan hadirnya Islam, yakni tawaran pendidikan ala kekaisaran yang diupayakan oleh pemerintah British Malaya dan Hindia Belanda, yang akhirnya bahwa pengetahuan etnologis Melayu yang terkonstruksi ini mempengaruhi proyek-proyek rekayasa sosial yang berkaitan dengan orang-orang Melayu.Schauer, Matthew J..Custodians of Malay Heritage: Anthropology, Education, and Imperialism in British Malaya and the Netherlands Indies 18901939 University of Pennsylvania, Pro Quest Dissertations Publishing, 2012. 354842. 
keyakinan mereka terhadap kebenaran dan kebaikan yang ada di dalam tradisi dan budaya tersebut. ${ }^{5}$ Kekayaan budaya tersebut pada masa lampau dan kini telah tersebar di wilayah yang cukup luas. ${ }^{6}$

Mempertegas hal di atas, jati Melayu dikenal dengan tiga hal, yaitu: berbudaya Melayu, berbahasa Melayu dan Beragama Islam. Ekspresi keberagamaan orang Melayu dari dulu sampai sekarang masih berpegang dengan slogan ${ }^{7}$ di tengah masyarakat Melayu Riau yang berisi "Melayu identik dengan Islam, tidak Melayu kalau tidak Islam. " Apa yang tersebut di atas menjadi penegas dan menjadi

${ }^{5}$ Ahmad 'Ubaydi Hasbillah, Ilmu Living Quran-Hadis: Ontologi, Efistemologi, dan Aksiologi, (Ciputat: Maktabah Darus Sunnah, 2019), 338.

${ }^{6}$ Tampak dari adanya naskah-naskah Melayu yang terdapat di berbagai belahan dunia (Asia, Afrika, Eropa dan Australia), terutama di 28 negara dengan jumlah naskahnya sebanyak 4000-10.000 buah. Kekayaan yang dimiliki itu tentu secara tidak langsung pula telah menjadi milik masyarakat yang mempelajarinya. Juga dari aspek kebahasaan, bahwa bahasa Melayu baru mencapai taraf linguna franca dalam arti yang sebenarnya setelah memperoleh dan menyerap berbagai istilah dari perbendaharaan bahasa Arab dan Persi, sehingga menjadikannya sebagai bahasa pengantar dalam penulisan yang bercorak Islam di seluruh Nusantara. Abd. Rachman Abror, Pantun Melayu Titik Temu Islam dan Budaya Lokal Nusantara, (Yogyakarta: LKiS, 2009), 77.

${ }^{7}$ Semboyan ini pula yang membedakan Melayu Riau dengan Melayu-Melayu di kerajaan lainnya, seperti kerajaan Samudra Pasai, kerajaan Aceh, kerajaan Aru, kerajaan Deli, kerajaan Serdang, kerajaan Langkat, kerajaan Asahan, Dhamasraya, Pagaruyung, Jambi, kerajaan Palembang, kerajaan Siak, Kerajaan Tanjung Pura, dan kerajaan Melayu yang tersebar di Nusantara lainnya. Lihat aneka kerajaan lainnya pada Ahmad Dahlan, Sejarah Melayu, (Jakarta: Kepustakaan Populer Gramedia, 2014), 424.

${ }^{8}$ Selogan yang dikatakan oleh Budayawan Riau UU. Hamidy bahwa penyatuan Islam dengan masyarakat Melayu sehingga Melayu menjadi identik dengan Islam, dapat dikatakan demikian dengan alasan karena kemampuan para pedagang menyesuaikan diri dengan kehidupan masyarakat, dan ini dapat dibenarkan. Namun kalau penyatuan tersebut karena Islam yang berkembang di tanah Melayu melalui jalur spritual/tasawuf yang sesuai dengan karakter masyarakat yang bergerak dari animinsme menuju masyarakat religius juga menjadi pembenaran dari persoalan di atas. Hal senada juga dinyatakan oleh Budayawan Tenas Effendy dalam karyanya Tunjuk Ajar Melayu, (Yogyakarta: Balai Kajian dan Pengembangan Budaya Melayu, 2011), 19.

${ }^{9}$ Dalam sejarah pernah terjadi pelepasan atribut sebagai orang Melayu secara besarbesaran pada dekade tahun 50-an, yaitu saat peristiwa "revolusi sosial" di kesultanan Deli Sumatera Utara. Pada saat itu, kekuasaan kesulthanan Deli sudah melemah sehingga banyak tokoh-tokoh di Kesulthanan Deli yang semula telah "masuk Melayu", keluar dari Melayu dan kembali ke suku asal ibunya, yaitu suku Batak Karo. Ismail Hussein, Tamaddun Melayu Menyongsong Abad Kedua Puluh 
realitas bahwa yang terjadi pada budaya Melayu Riau tidak semestinya terjadi hal-hal yang menodai slogan yang sudah popular sedemikian rupa. Keadaan ini bisa terjadi, karena rangkaian aktivitas sampai ujudnya suatu budaya, dipandang sebagai suatu kesadaran daripada pemeluk agama untuk mewujudkan pandangan hidupnya. ${ }^{10}$ Hal ini sangat beralasan sebab Agama Islam mempunyai padangan yang cendrung tidak terpisahkan. Ini ada hubungan dengan konsep Islam, bahwa agama (Islam) ini sejatinya diterima secara kaffah (totalitas). ${ }^{11}$ Sebagaiman termaktub dalam (QS. Al-Baqarah [2]: 208). ${ }^{12}$

Tradisi dan budaya yang sudah mengakar pada upacara tradisional Melayu Riau, dalam kajian hal ini adalah upacara manumbai (upacara ritual mengambil madu lebah), yang manyisakan terdapat anomali dalam peraktek upacaranya. Apa yang tampak di permukaaan dalam sisi praktek budaya manumbai masih memunculkan sesuatu yang anomali dalam sisi kebudayaan Islam

Satu, (Bangi: University Kebangsaan Malaysia, 2001), hal. 18-19. Lihat juga Isjoni Ishak (ed), Antara Streotip dari Jati Diri Orang Melayu dalam "Orang Melayu“ Sejarah, Norma dan Adat Istiadat”(Pekanbaru: UNRI Press, 2002), 50. Lihat pula Junaidi, "Islam dan Kebudayaan dalam Tunjuk Ajar Melayu", (Riau Pos, Ahad, 10 April 2011), 19.

${ }^{10}$ Maksud pandangan hidup di sini adalah "sesuatu yang dipandang baik dan benar". Sebab itu yang akan ujud dalam rangkaian tingkah laku tentulah sesuatu yang dipandang benar.UU. Hamidy, Orang Melayu di Riau, (Pekanbaru: UIR Press, 1996), 133.

${ }^{11}$ Kăffah ditafsirkan dalam kitab Jalalain yaitu dengan masuk kedalam Islam dengan seluruh keadaan lahir maupun bathin. Lihat dalam Louis Ma'luf, al-Munjid fi al-Lughah wa al- A'lam, Beirut: Dar-al-Mushriq, 1976, hal. 689. Lihat juga Imam Jalāluddin al-Mahallị dan Imam Jalāluddin al-Suyūtī, Tafsir Jalālain, (Beirut: Dâr al-Kutub, 2002), 30.

${ }^{12}$ Maksud ayat di atas antara lain, adalah, menyatukan akal dan hati, jangan berlaku seperti setan yang memisahkan antara hati dan akalnya, serta menyulut peperangan antara perasaan dan pengetahuannya. Pada saat seseorang menyerahkan diri secara fisik, nalar dan jiwanya kepada Allah SWT, dan Rasul, maka baru pada saat itu dia dinamai Muslim sejati. kemudian dapat pula dimaknai dari ayat di atas adalah bahwa kepasrahan secara total kepada Allah SWT akan melahirkan pribadi-pribadi yang memiliki ketulusan hati dan kesucian jiwa, yang kemudian menjadi unsur penting dalam mewujudkan masyarakat yang sejahtera adil dan makmur. M. Quraish Shihab, Menabur Pesan Ilahi, Al-Qur'an dan Dinamika Kehidupan Masyarakat, (Jakarta: Lentera Hati, 2006), 15. Lihat juga Muchlis M. Hanafi (ed), Tafsir Al-Qur'an Tematik, Amar Makruf Nahi Mungkar, (Jakarta: Lajnah Pentashihan Mushaf Al-Qur'an, 2013), 36. 
Rekonsiderasi Budaya Manumbai Masyarakat

yang dilandasi dengan spirit dan nilai-nilai al-Qur'an. Hal ini bisa saja menepis slogan yang tersebut di atas.

\section{Manumbai pada Budaya Melayu Riau}

Membicarakan suatu kegiatan budaya seperti menumbai (upacara mengambil madu lebah) pada masyarakat Petalangan Melayu Riau adalah merupakan suatu kajian yang mempelajari aspekaspek atau kelompok masyarakat tertentu dalam hubungannya dengan alam pikiran, perasaan dan cara mereka memandang alam. ${ }^{13}$ Jika dilihat dari segi makna bahasa, maka manumbai diduga berasal dari kata tumbai atau umbai, dan arti kata-kata itu antara lain ialah turun, menurunkan. Makna itu masih tampak dalam kata umbain (turunkan dari atas ke bawah) dengan mempergunakan suatu alat maumbaian (menurunkan) misalnya tali dan bakul. Dalam kegiatan menumbai memang tampak ada makna gerak menurunkan suatu dari atas, yaitu menurunkan madu lebah dengan mempergunakan tempat madu yang disebut timbo (timba). Timbo diumbaikan atau diturunkan ke bawah dengan mempergunakan tali. Meskipun demikian, yang lebih penting lagi tentulah makna upacara sebagai budaya masyarakat Petalangan dalam keseluruhan kegiatan kehidupan mereka. ${ }^{14}$

\footnotetext{
${ }^{13}$ Kajian serupa itu lazim disebut sebagai kajian Antropologi budaya. Dengan konsep itu, sebenarnya seseorang akan mengamati ekspresi manusia dalam bentuk dan arti simbol-simbol yang dipergunakan oleh suatu komunitas tertentu. Apa yng dilakukan dalam praktek kebudayaan di suku Petalangan yaitu menumbai adalah; harus dilihat dari aspek referensi dan intrepretasi berbagai simbol dan kiasan yang mereka pakai dalam dunia kehidupan mereka. Maka ketika itu terjadi, sesungguhnya bahasannya bukan pada persoalan logis atau tidak logis. Cara berpikir masyarakat seperti itu, bukan sebenarnya tidak logis. Yang benar menurut John Beattile ialah mereka berpikir secara simbolik dan kiasan. UU. Hamidy, Rimba Kepungan Sialang, Jakarta: Balai Pustaka, 1987, hal. 95.

${ }^{14}$ Orang Petalangan terbagi dalam suku-suku (matrilineal lineage group), yaitu Sengerih, Lubuk, Pelabi, Medang, Piliang, Melayu, Penyabungan dan Pitopang (menurut tombo Petangan, suku Penyabungan dan suku Piliang diyakini berasal dari Minangkabau- (Sumatera Barat). Secara Bahasa mereka manyoritas memakai dialek lokal Melayu Riau yang dikenal sebagai "bahasa Melayu Kampar”. Bahasa Indonesia baku sesekali digunakan oleh pemimpin desa dalam konteks resmi. Secara agama orang Petalangan beragama Islam. Meskipun menyatakan diri sebagai muslim, sebagian besar warganya percaya akan adanya mahkluk gaib. Mereka percaya bahwa setiap makhluk di dunia memilki roh penjaga okuan. Menurutnya kehidupan dan kesejahteraan makhluk hidup-termasuk tumbuhan, binatang dan manusia-sangat tergantung pada makhluk yang menghuni alam gaib.
} 
Upacara menumbai menampakkan diri dalam warna kehidupan mereka sebagai kekuatan kiasan melalui pengucapan halus. Karena itu menumbai juga memperlihatkan dirinya berupa kekuatan batin, yang sering dalam istilah antropologi disebut kekuatan magis. Kekuatan kiasan yang mempergunakan pengucapan halus berupa pantun-pantun dalam manumbai lebah sialang, ${ }^{15}$ bisa dilihat dari segi dunia budaya pada sisi esoteric-nya, serta yang utama dari segi alam pikiran persukuan petalangan warisan tradisi lama. Keduanya tampak berbaur dalam manumbai, sehingga makrifat-nya berpilin dalam bentuk dua tali pandangan batin tersebut. Dalam pengertian yang lebih luas manumbai boleh dikatakan sebagai kegiatan budaya mengambil madu lebah. Dalam pengertian yang lebih sempit, manumbai merupakan penggunaan mantera dan pantun-pantun sebagai pengucapan yang halus dalam upaya "menggoda lebah" untuk dapat mengambil madunya. Meskipun segala upaya lahiriah telah dilakukan berupa membuat semangkat, memakai tunam dan memanjat pada malam gelap. Namun bagi pandangan pesukuan di Petalangan, upaya lahir itu belumlah memadai. Dalam pandangan mereka tetap ada sutau segi kekuatan batin, kekuatan yang tak dapat dijangkau dengan upaya lahiriah. Kekuatan batin yang gaib itu lebih hebat daripada kekuatan lahiriah. Sebab itu melakukan suatu pekerjaan dengan kekuatan lahir-lahir saja tidaklah akan mencukupi,

Selain okuan, terdapat beberapa jenis makhluk gaib lainnya seperti jin, mambang, deo (dewa), jembalanag, orang bunyian, penunggu atau puaka, hantu dan lain lain. Mereka percaya, makhluk gaib itu ada yang baik ada yang jahat. Makhluk gaib yang baik seperti okuan dapat dijadikan sahabat. Untuk menjaga hubungan dengan alam gaib, mereka melaksanakan berbagai ritual dan mematuhi pantang-larang, agar makhluk gaib yang baik tetap bersahabat dengan mereka dan yang jahat tidak menggganggu atau mendatangkan bencana. Elmustian Rahman, et, al. Ensiklopedi Kebudayaan Melayu Riau, Jilid IV. Pekanbaru: Pusat Penelitian Kebudayaan dan Kemasyarakatan Universitas Riau, 2012. hal. 80-81.

${ }^{15}$ Kayu Sialang telah dipercayai sebagai kayu yang sakti. Sebagai kayu yang sakti, kayu itu pertama-tama dianggap mempunyai penghuni. Penghuni dalam bentuk gaib dinamakan mambang kayu, jembalang, bahkan orang bunian. Sedangkan penghuni lahiriah ada yang berupa ular, kala dan lipan. Karena ada penghuni serupa inilah lebah sialang dipercayai memilih pohon itu tempat bersarang. Sebagaimana burung tempua juga bersarang dengan keadaan yang serupa, sehingga jadi terkenallah peribahasa 'kalau ada tak berada tidaklah tempua berearang rendah". UU. Hamidy, Rimba Kepungan Sialang, Jakarta: Balai Pustaka, 1987, hal. 100 . 
Rekonsiderasi Budaya Manumbai Masyarakat

Petalangan Melayu Riau Berbasis Al-Qur'an

tanpa dilengkapi dengan upaya memperoleh kekuatan batin yang gaib. ${ }^{16}$

Setelah sekitar pohon sialang dibersihakan, maka dibuatlah pondok tempat berjaga. Juragan tua pergi ke banir atau pangkal pohon membawa suluh untuk mengusir binatang-binatang berbisa yang mungkin bersarang di pangkal pohon tersebut. Setelah tandatanda binatang berbisa tidak ada lagi, maka juragan tua membacakan mantera. ${ }^{17}$ Mantera itu bertujuan membujuk penghuni sialang itu, agar tidak mendatangkan bahaya kepada mereka yang akan memanjatnya. Tindakan budaya itu disebut manuokan sialang (menuakan sialang). Menuakan sialang berarti dituakan identik

${ }^{16}$ Dapat dicontohkan bahwa dalam hal ritus pengobatan dan praktik magis orang Petalangan, yang menguak inti kultural mereka mengenai harmoni dan tolongmenolong antara makhluk hidup dan mahkluk gaib yang disentesakan dengan Islam, masih hadir dalam kehidupan sehari-hari. Beberapa praktik religi tradisonal, bahkan telah diolah dan direvitalisasi dalam bentuk 'tradisi', 'kesenian', dan 'kebudayaan' yang mencerminkan nilai -nilai warisan leluhur. Misalnya, ritualritual belian, menetau tanah, membuka hutan, mandi air jejak tanah, termasuk manumbai, mendirikan bangunan atau menegakkan rumah dan beramu kayu. Mereka tidak menganggap kepercayaan sehari-hari ini bertentangan dengan identitas Islam mereka. Malahan identitas Islam ini menjadi sumber kekuatan lain yang mendukung kekuatan spiritual mereka. Elmustian Rahman, et,al. Ensiklopedi Kebudayaan Melayu Riau, Jilid IV. Pekanbaru: Pusat Penelitian Kebudayaan dan Kemasyarakatan Universitas Riau, 2012. hal. 81.

${ }^{17}$ Mantera adalah ucapan berdaya magis yang digunakan dalam aktivitas kehidupan sehari-hari oleh masayarakat Melayu tradisional. Mantera dapat digunakan sebagai pelangkah, penjaga diri, penjaga harta benda, penyampai maksud, permohonan atau pengharapan, untuk permainan rakyat termasuk olah raga dan sebagainya. Istilah mantera merupakan sebutan yang paling umum dipakai, kerabat dari istilah mantera tersebut dapat disamakan dengan serapah, jampi, tawar, tangkal, cuca dan oja. Di alam Melayu, mantera sudah ada dan dikenal atau berkembang semenjak manusia purba. Mantera sebagai permualaan bentuk puisi tradisional. Sebagai salah satu puisi tradisional, mantera dianggap memiliki karakteristik yang khas apabila dibandingkan dengan jenis puisi tradisonal lainnya. Kekhasan itu tampak pada kesakralan atau kekuatan yang ditimbulkannya. Dari aspek kepenuturannya pun menampakkan kekhasan pula. Sebagai jenis puisi yang memiliki kesakralan dan kekuatan gaib, mantera dituturkan hanya oleh orang-orang tertentu yang memenuhi persyaratan tertentu untuk itu. Orang-orang yang dimaksud biasanya pawang, dukun atau bomo. Mereka ini dipandang oleh masyarakat sebagai orang yang memiliki nilai lebih dan dipercayai merupakan orang yang siap menolong dan menyelamatkan masyarakat dari segala merabahaya yang mengancamnya. Elmustian Rahman et. al., Ensiklopedi Kebudayaan Melayu Riau, Jilid III. Pekanbaru: Pusat Penelitian Kebudayaan dan Kemasyarakatan Universitas Riau, 2012, hal. 311-312. 
Rekonsiderasi Budaya Manumbai Masyarakat

dengan menghormati atau memuliakan, dan sesuatu yang telah dituakan diharapkan tidak akan memberi mudarat kepada pihak yang menuakannya.

Dalam mantera itu antar lain dibacakan pengucapan halus, yang maksudnya kalaulah memang sialang itu dilingkari ular tedung dan naga (lambang dari penghuninya) maka diharapkan tetaplah juga hendaknya (selama pohon itu di panjat) di banir kayu itu. ${ }^{18}$ Pada pandangan batin juragan tua dan juga juragan muda, atau juragan pembantu yang memanjat sialang-sialang itu digambarkan sebagai manusia, sehingga bagian-bagian pohon itu membentuk suatu gambaran kekeluargaan dengan juragan itu sendiri. Selaras dengan pandangan kiasan itu, maka pangkal pohon sialang telah dimakrifatkan sebagai diri kita sendiri. Dahan jombang yaitu dahan yang tertua atau dahan yang pertama dari bawah, dikiaskan dalam batin sebagai istri kita (juragan), sedangkan pucuk pohon sialang yang disanjung dengan Tuhan Putri Nilam Cahaya, dimakrifatkan sebagai anak kita (juragan). Dengan begitu, antara pemanjat (juragan) dengan sialang itu sendiri sudah tak ada batas pemisah dalam pandangan batin atau makrifat. Hal itu dipercayai tidak lagi akan mendatangakan malapetaka kepadanya. ${ }^{19}$

Jika mantera sudah dibaca, dan makrifat telah putus dalam pandangan batin, maka juragan tua itu membaca simbol atau kiasan yang terjadi setelah pembacaan itu. Jika tidak ada tanda-tanda buruk dipangkal pohon sialang itu, maka dapatlah dipasang semangkat sampai mendekati dahan jombang. Sesudah itu pemasangan semangkat dihentikan sampai Maghrib atau malam hari. Jika sialang itu cukup rendah, maka semangkat semuanya bisa dipasang di malam hari. Setelah selesai sembahyang Magrib, maka tibalah semua pihak penumbai itu. Warga masyarakat sekitar itu juga banyak yang ikut

\footnotetext{
${ }^{18}$ UU. Hamidy, Rimba Kepungan Sialang, Jakarta: Balai Pustaka, 1987, hal.101.

${ }^{19}$ Cara "menggoda" binatang dan tumbuhan melalui semacam pandangan batin, tentu saja dengan menyimbolkan alam serupa itu sebagai manusia. Jika di Petalangan lebah telah dipandang dalam pandangan batin sebagai manusia, maka di Rantau Kuantan, enau, juga telah dipandang dalam sikap dalam sikap serupa itu sebagai perempuan pula. Tetapi keduanya tampak mendapat keistimewaan demikian rupa, karena baik lebah maupun enau, amat diperlukan oleh manusia di sekitarnya. Lebah dan enau sama-sama memberikan manisan. Tampaknya ada kecendrungan membuat simbol sesuatu yang manis dengan perempuan. Lihat lebih jauh pada UU Hamidy, Kasin Niro Penyadap Enau Rantau kuantan, Pekanbaru: Puslit Universitas Riau, 1983. hal. 43.
} 
Rekonsiderasi Budaya Manumbai Masyarakat Petalangan Melayu Riau Berbasis Al-Qur'an

melihat. Ketika semuanya telah siap (tunam, timbo, tali timbo, ember atau kaleng dan berbagai perlengkapan lainnya) dan juragan tua serta juragan muda telah berada dalam konsentrasi yang tinggi, maka dimulailah upacara manumbai. ${ }^{20}$

Ritual Menumbai ${ }^{21}$ selalu berlangsung di dalam gelap malam tak berbulan, karena jika lebah melihat cahaya maka dia akan marah

\footnotetext{
${ }^{20}$ Walupun demikian, bisa dimaknai acara manumbai mengandung arti sosial dari simbol bisa dilihat dalam berbagai kehidupan. Selain madu lebah sebagai benda menarik minat dalam pesukuan Petalangan, namun madu lebah bagi masyarakat Petalangan tidaklah dapat dipandang sebagai milik juragan dengan beberapa pihak yang tampaknya mempunyai sangkut-paut dengan rimba kepungan sialang. Bagi mereka semua harta benda dan hak-hak perorangan berfungsi sosial, artinya hakhak itu tidak boleh digunakan secara bebas menurut selera pemiliknya. Setiap penggunaan hak harus dibenarkan oleh fungsinya dalam golongan atau pesukuan. Karena itulah hasil madu sialang itu telah di bagi-bagi sesuai dengan fungsi hak tersebut dalam pesukuan di daerah itu. Pembagian bisa dikategorikan atas dua cara. Pertama, apakah sialang itu merupakan kepunyaan (telah diserahkan mengelolanya oleh batin) suatu suku juragan termasuk ke dalam suku yang diberi hak mengelolanya. Kedua, apakah pihak juragan berada di luar suku yang mengelola sialang tersebut. Jika pihak jurgan muda dan tua terhitung di luar suku yang mengelola rimba kepungan sialang tersebut, maka pembagian untuk pihak mereka cukup besar. Ada kira kira $40 \%$. selebihnya $40 \%$ lagi untuk semua anggota suku. Sedangka sisanya $20 \%$ lagi untuk kepala suku. (seperti batin dan pembesar adat lainnya) tukang sambut, dan para tamu yang dihormati. UU. Hamidy, Rimba Kepungan Sialang, Jakarta: Balai Pustaka, 1987, hal. 112.

${ }^{21}$ Terkait dengan ritual dan siklus kehidupan yang ada di Petalangan, dapat dibagi dalam tiga frasa. Pertama; sebelum Islam masuk. Pada masa ini masyarakat Petalangan sangat percaya pada mahkluk-makhkuk gaib penunggu hutan dan pohon besar. Inilah salah satu yang mempengaruhi sehingga di beberapa ritual Petalangan terdapat beberapa bagian yang menunjukkan hubungan ini. Misalnya pada ritual sema kampung. Pada ritual ini masyarakat dahulunya melakukan pemotongan hewan kerbau atau sapi dan membawa kepala hewan itu ke tengah hutan. Tujuannya supaya desa atau kampung mereka terhindar dari bala yang mengancam. Kedua; awal masuknya Islam. Pada masa awal ini terjadi percampuran antara kepercayaan terhadap makhluk gaib dan ajaran Islam. Sehingga terjadi perpaduan antara pembacaan mantra magi dengan kalimat lafazd Allah. Bahkan belakangan mereka sudah tidak lagi menyebut rapalan mantera sebagai mantera, tetapi dengan menyebutnya sebagai doa (bacoan). Di awal mantera biasanya diawali dengan pengucapan "Bismillahirrahmanirrahim" dan diakhiri dengan menyebut "berkat kalimat lailahaillah'. Ketiga; zaman sekarang. Pesatnya perkembangan Islam telah pula mempengaruhi pola laku masyarakat Petalangan. Beberapa tradisi yang dianggap sudah menyalahi syara', mulai ditinggalkan atau diubah sedemikain rupa mengikuti ajaran syara' 'menyema kampong". Namun sekarang lebih banyak dilakukan doa dan dzikir keliling kampong menggantikan pengucapan manteramantera yang ada. Elmustian Rahman, et,al., Inventarisasi Kesusantraan Daerah
} 
dan menyengat orang-orang. Ritual dimulai dengan pelafalan mantera magi oleh juragan. Setelah mantera diucapakan perlahan, ia menepuk batang pohon dan menunggu jawaban dari lebah-lebah. Suara ribuan lebah yang berdengung menandakan 'izin' bagi juagan memanjat pohon. Jika tidak mendengar jawaban, maka pemanjatan ditunda. Selanjutnya, setelah menerima jawaban dari lebah-lebah, juragan mulai menyanyikan lagu-lagu ritual sambil mengelilingi pohon sialang tiga kali. Lagu pertama dari tiga lagu yang dinyanyikan di bawah pohon disebut "menuo sialang" yang berarti "menghormat sialang." Isi lagu-lagu ini memberi penghormatan pada roh Sialang, dengan memanggilnya sebagai "tuan" pohon sialang. Setelah mengelilingi pohon, juragan memanjat dan mengusap sarang lebah dengan obor membara, sehingga lebah-lebah yang telah dimanterai pun berjatuhan, berkilauan ke tanah. ${ }^{22}$ Ketika seluruh lebah sudah meninggalkan sarangnya, juragan mengambil lilin lebah, lalu dengan tali dan wadah diulurkannya kepada pembantu yang menunggu di bawah bersama kepala suku. Proses ini terus berulang sampai Subuh atau sampai pengambilan madu selesai.

\section{Term al-Ghuluw dalam Al-Qur'an}

Kata al-ghuluw (الغلوّ) dari kosa kata ini dan bentukanbentukannya berkisar satu makna yang menunjukkan sikap melampaui batas dan ketetapan. Menutut Ibnu Faris, "Huruf dasar dari ghain, lam dan 'illah' menunjukkan sesuatu yang meninggi, melanggar dan melampaui batas'. ${ }^{23}$ Dengan begitu, dapat dikatakan Ghalā, ghalāan fahuwa ghālin'. Jika dikatakan ghalā fí al-umüri ghuluwwan artinya melampaui batasan tertentu. Ghalauta bi al-sahmi artinya engkau melepaskan anak panak hingga melampaui batas yang

Pelalawan, Pekanbaru: Dinas Kebuadayaan dan Kesenian dan Pariwisata, 2007, hal. 34.

${ }^{22}$ Mereka tidak membunuh lebah-lebah itu orang Petalangan mengatakan bahwa lebah-lebah yang sudah dimanterai itu pingsan dan tidak dapat terbang ke sarangnya hingga matahari terbit. Pagi harinya, lebah-lebah itu akan kembali terbang ke pohon. Perhatian untuk menjaga lebah tetap hidup adalah untuk kelangsungan produksi madu. Yoonhee Kang, Untaian Kata Leluhur, Marjinalitas, Emosi dan Kuasa Kata-Kata Magi di Kalangan Orang Petalangan Riau, diterjemahkan oleh Siti Rohana dari judul Words of the Ancestors, Words for Survival: Marginality Emotion and the Power Magical Words among the Petalangan of Riau, Pekanbaru: Gurindam Press, 2012, hal. 103.

${ }^{23} \mathrm{Abi}$ al- Husein Ahmad Ibn Zakariyā Ibn Fāris, Mu'jam Maqāyis al-Lugah, ditahqiq oleh Abd al-Salām Muhammad Hārūn, Beirut: Dār al-Fikr, t. th, hal. 697. 
Rekonsiderasi Budaya Manumbai Masyarakat Petalangan Melayu Riau Berbasis Al-Qur'an

diperkirakan atau ditentukan. Ghuluw juga berarti melampaui batas (التجاوزُ فى الأمر ) 'ghalā fí al-din ghuluwwan' artinya 'bersikap keras hingga keluar dari batasannya'. ${ }^{24}$

Kata ini juga huruf dasar merupakan bentuk masdar dari kata 'ghalā-yaghlū' (غلا- يغلو) yang secara etimologi berarti melampaui batas. Pendapat lain mengatakan dalam mu'jam al-I'lam bahwa alghuluw (الغلوّ) bermakna 'al tatarruf fí al-amr' (التطرف فى الأمر '25 yakni 'menjadi ekstrim, menjadi berlebih-lebihan, menjadi

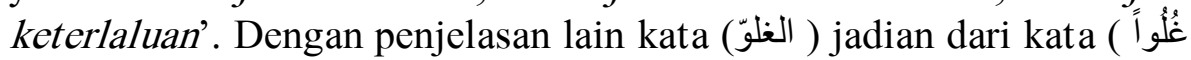
(و غلاءً kalau dimaknai dengan: "Jawāz al-ḩad' maka berartikan "berlebih-lebihan atau melampaui batas". Atau dimaknai dengan

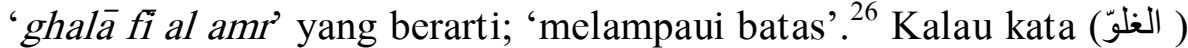
jelmaan dari (غَلَا) bermakna "melampaui batas" apabila digunakan dalam kalimat (في السعر غلاء 'as-si'r ghalā'). (pada untaian syair yang melampaui batas), dan pada kata (غلوَّفى القدر والمنزلة)/fĩ 'al-Kadr wa almanzilah' (pada batas dan tempat keterlaluan). Penjabaran ini sebagaimana terdapat termaktub dalam QS. Al-Nisā' [4]: 171.

Sedangkan kata ( الغليُ و الغَلَيانُ / al-ghulyu wa al-ghulyān)

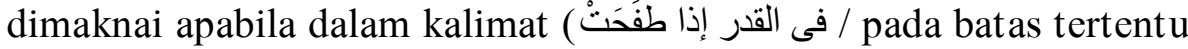
apabila dia sudah meluap) terdapat pada QS. Al-Dhukhān [44]: 4446. ${ }^{27}$ Terkait lafadz yang berhubungan dengan kata (الغلوّ) adalah Tatarruf, yang berkisar maknanya pada dua aspek yaitu: pertama; batasan sesuatu, dan kedua; gerakan dalam sebagian anggota badan. Maka yang difokuskan dalam pembahasan ini adalah makna pertama, yaitu batasan sesuatu dan pinggiran atau tepiannya. Adapun maksud yang pertama di atas adalah ujung dan puncak sesuatu. Hal ini dapat

\footnotetext{
${ }^{24}$ Abdul Hamid Mushțafā al-Sayyid, al Af'āl fì al-Qur'ān al-Karìm, Ommān: Dār wa maktabah al-Hamid, 2003, Juz 2, hal. 1002.

${ }^{25}$ Abdul Șabūr Marzūk, Mu'jam al I'lām wa al-Mauḍu'āt fí al-Qur'ān al-Karìm, Kairo: Dār al-Shurūq, 1995, Jilid 2, hal. 986. Lafaz 'Tatarruf merupakan bentuk kata kerja dari tarf (طرف) yang berarti 'menghampiri tepian'. Makna seperti ini biasa dikatakan orang ketika matahari hampir terbenam. Apakah makna al-tarf adalah ujung sesuatu atau maknanya merupakan kemutlakan batasan. Artinya bahwa siapa saja yang melampaui batas garis tengah secara berlebih-lebihan, maka menurut bahasa dia sudah bisa disebut mutatarrif. Majuddin Muhammad bin Ya'qūb al-Fairuz Abadi, al-Qāmus al-Muhịt, Beirūt: Dār al-Jaìl, t.tp. Jilid 2, hal. 80.

${ }^{26}$ Ahmad Warson Munawwir, Al-Munawwir Kamus Arab Indonesia, Surabaya: Pustaka Progresif, 1997, hal. 1015.

${ }^{27}$ Abū al-Qāsim Abū al-Husain bin Muhammad al-Rāgib al-Ishfahānī, Al-Mufradāt fi Garīb al-Qur'ān, Mesir: Mustafā al-Bāb al-Halabì, 1961, hal. 275.
} 
saja berlaku bila tidak ada kesamaan kedua batasnya, sehingga masing-masing di antara keduanya dapat menjadi permulaan dan ujung penghabisan, dapat dicontohkan seperti dua titik sebuah garis. Karena itu dikatakan dalam ungkapan (تطرفت الثمس) artinya hampir

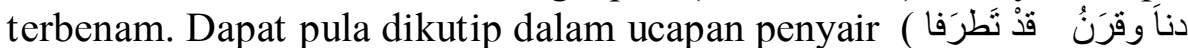
artinya mendekati garis ufuk ketika hendak terbenam. ${ }^{28}$

Dalam salah satu syair dikatakan (أعْرِف طرفهُ ) artinya ketahuilah kesudahan orang itu jika ia disingkirkan. Sebagaimana dimaklumi, jika sesuatu disingkirkan, tentu ia akan sampai ke ujung dan kesudahnnya, seperti yang juga dikatakan terhadap unta, jika ia sedang di gembala dipinggir tempat gembalaan (طرفت الناقَة) artinya unta itu berada dipinggir. Perkataan lain yang serupa (تطرّفت الناقة (طرة) demikian penjelasan al-Fairūz Abadi, ketika menjelaskan makna kata tarf yaitu ujung dan pengahabisan segala sesuatu. ${ }^{29}$

Dikatakan dalam mu'jam al-Wasit (الطرف من كل شيء) artinya ujung sesuatu atau sisi atau tepiannya. Lafaz tatarruf merupakan bentuk kata kerja dari tarf. Tatarrafa-yatatarrafu-fahumāmuthataharrif, yang berarti 'menghmpiri tepian'. Makna seperti ini biasa dikatakan orang ketika matahari hampir terbenam. Apakah makna "at-tarf" adalah ujung sesuatu atau maknanya merupakan kemutlakan batasan. Dengan kata lain siapa saja yang melampaui batas garis tengah dan berlebihan-lebihan, maka menurut bahasa dia sudah bisa dikatakan mutatarrif. Disebutkan pula dalam mu'jam alwasit tentang makna tatarrafa artinya 'melewati batas garis tengah dan tidak mengambil jalan tengah,30 Kata al-ghuluw (الغلوّ) baik dalam bentuk kata kerja, dengan makna التطرف فى الأمر pada pelarangan yang jelas tersebut dalam al-Qur'an 2 (dua) kali yaitu tersebut satu kali pada QS. Al-Nisā' [4]: 171, dan 1 (satu) kali pada QS. Al Māidah [5]: 77. ${ }^{31}$

\footnotetext{
${ }^{28}$ Sayyid Muhammad Murthaḍ̄a al-Husainī al-Zubaidi, Tāj al-'Arus min Jauhari alQāmūs, Beirūt: Dār al-Ihyā al-Turāthì al-'Arabì, 1987, hal. 89.

${ }^{29}$ Majuddin Muhammad bin Ya'qūb al-Fairūz Abāđì, al-Qāmus al-Muhït, Beirūt: Dār al-Jaill, t.tp. Jilid 2, hal. 79.

${ }^{30}$ Ibrāhim Madkūr, Mu'jam al-Wasịt, tp. Dār al-Hindusiyah, 1985, Jilid. 2. hal. 575.

${ }^{31}$ Muhammad Fuad 'Abdul Baqi', al-Mu'jam al-Mufahras li al-Fā al-Qur'ān, Beirūt: Dār al-Fikr, 1994, hal. 616.
} 
Rekonsiderasi Budaya Manumbai Masyarakat

\section{Tinjauan al-Qur'an tentang Pelarangan al-Ghuluw}

Manumbai adalah salah satu upacara tradisional yang dilakukan suku Petalangan Riau. Tinggal di hutan pedalaman ${ }^{32}$ membuat hidup mereka sangat bergantung pada hasil hutan. Selain ikan dan karet, madu adalah salah satu hasil hutan yang penting, yang mereka jual di kota kota kecil terdekat dan sepanjang jalan utama yang menghubungkan kota-kota tersebut. Penduduk kampung seringkali membangun pondok kecil dan kios untuk menjajakan botol-botol madu tersebut dan menarik perhatian orang-orang yang lewat.

Menurut kepercayaan, madu dan pohon tempat melekatnya sarang lebah yang disebut sialang, dimiliki oleh roh-roh hutan. Manusia hanyalah pengguna, sementara-orang Petalangan cenderung menyatakannya sebagai "pemakaian" bukan "kepemilikan" terhadap sumber-sumber alam. Pohon sialang dan hutan yang mengelilinginya bukanlah milik pribadi, namun hak milik publik masing-masing suku. Sebagai unit praktis untuk ekonomi subsistensi dan aktivitas keluarga sehari-hari, masing-masing suku mengatur pengumpulan dan distribusi madu serta sumber alam lainnya. Ketika pohon sialang dengan sarang lebah liar ditemukan sarat dengan madu, pemimpin suku mengatur sebuah kelompok untuk mengambilnya. Kelompok tersebut terdiri atas dukun lebah (yang disebut juagan/juragan atau dukun lebah) yang akan memanjat pohon, dan pembantunya (disebut dukun sambut) yang mengumpulkan madu setelah juagan/juragan mengambil sarang dari dahan. Anggota suku yang lain membuat tangga atau rangka-rangka kayu untuk memanjat pohon dan mencapai dahan-dahannya. Jumlah kelompok sekitar sepuluh orang dan semuanya laki laki. ${ }^{33}$

\footnotetext{
${ }^{32}$ Masyarakat Melayu Petalangan yang mendiami belantara Pangkalan Kuras berada pada 17 kampung atau desa. Mereka berasal dari beberapa puak Melayu di sekitarnya seperti Rantau Kuantan, Kampar, Malaysia dan Minangkabau. Ragam suku itu telah lebur ke dalam warna budaya, sehingga dialek Melayu Petalangan ini membayangkan ada warna dialek Kampar, Kuantan dan Minangkabau. Mereka mendiami daerah Petalangan ini diperkirakan sekitar 150-170n tahun yang silam. Leluhur puak Melayu Petalangan yang paling terpandang adalah datuk Demang Serail. Dialah tokoh masyarakat yang pertama membuka kampung di sana. Karena beliau menyangkutkan gongnya pada kayu kuras, maka itulah sebabnya daerah Petalangan itu disebut Pangkalan Kuras. UU. Hamidy, Negeri Rantau, Pekanbaru : Bilik Kreatif, 2017, hal. 254-255.

${ }^{33}$ Dalam masyarakat Petalangan, ada juga julukan untuk dukun, yaitu "dukun" dan "kemantan". Sebagai pelaku biasa, dukun hanya bergantung pada mantera dan
} 
Apa yang dilakukan dalam peraktek mengambil madu lewat preses nyanyian ala masyarakat sialang merupakan indikasi dari adanya memperlakukan alam lingkungan mereka dalam kategari al ghuluw atau "melampaui batas" yang berlebihan disaat prosesi "pemujaan" terhadap pohon sialang.

Dalam hal ini QS. An Nisa' [4]: 171, memberi isyarat sebagai berikut:

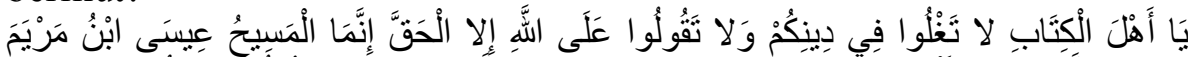

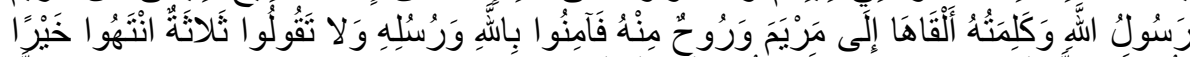

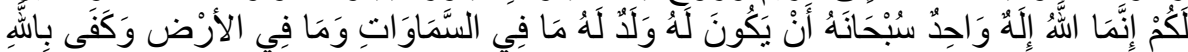

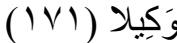

171. Wahai ahli Kitab, janganlah kamu melampaui batas dalam agamamu[383], dan janganlah kamu mengatakan terhadap Allah kecuali yang benar. Sesungguhnya Al Masih, Isa putera Maryam itu, adalah utusan Allah dan (yang diciptakan dengan) kalimat-Nya[384] yang disampaikan-Nya kepada Maryam, dan (dengan tiupan) roh dari-Nya[385]. Maka berimanlah kamu kepada Allah dan rasul-rasulNya dan janganlah kamu mengatakan: "(Tuhan itu) tiga", berhentilah (dari Ucapan itu). (Itu) lebih baik bagimu. Sesungguhnya Allah Tuhan yang Maha Esa, Maha suci Allah dari mempunyai anak, segala yang di langit dan di bumi adalah kepunyaan-Nya. cukuplah Allah menjadi Pemelihara.

Dalam ayat di atas dimulai dengan "ya ahlal Kitab" maksudnya adalah lafaz umum yang dimaksudkan adalah khusus, mereka adalah kaum Nasrani berdasarkan firman lanjutan ayat di atas 'wala taqulu stalasah", ini adalah perkataan kaum Nasrani. Sedangkan kata 'al ghuluw" bermakna melampaui batas. ${ }^{34}$ Ahli kitab dalam ayat di atas maksdunya adalah Kitab Injil, (la taghluw) maksudnya adalah dalam agamanya, Dengan maksud agar mereka jangan melampaui batas dalam agamanya. Kemudian janganlah mereka hendaknya

penggunaan tumbuhan dan benda-benda untuk mengobati orang sakit, sedangkan kemantan mengobati pasien dengan membangkitkan roh halus yang disebut dengan belian. Kekuatan kemantan dianggap lebih hebat daripada dukun. Biasanya sebuah suku hanya memiliki seorang kemantan. Yoonhee Kang, Untaian Kata Leluhur, Marjinalitas, Emosi dan Kuasa Kata-Kata Magi di Kalangan Orang Petalangan Riau, diterjemahkan oleh Siti Rohana dari judul Words of the Ancestors, Words for Survival: Marginality Emotion and the Power Magical Words among the Petalangan of Riau, Pekanbaru: Gurindam Press, 2012, hal. 59.

${ }^{34}$ Muhammad Ali al-Ṣābunī, Safwah al-Tafāsir, Kairo: Dār al-Ṣābūnīi, 1976, jilid. 1, hal. 320. 
mengatakan terhadap Allah SWT kecuali ucapan (al-haq) yang benar yaitu mensucikan-Nya dari kemusyrikan dan mempunyai anak. $^{35}$

Ahli Kitab yang maksud pada ayat ini adalah kaum Nasrani, yang dilarang melampaui batas dalam mengamalkan ajaran agama, dalam arti kata janganlah melampaui batas-batas kebenaran. Kekeliruan yang dilakukan Nasrani adalah terkait dengan Isa as, dan posisinya sebagai anak Tuhan. Untuk itu Allah SWT menurunkan ayat di atas. ${ }^{36}$

Menurut Wahbah mengandung penjelasan tentang aspek sejumlah hukum, diantaranya adalah pada aspek Sikap berlebihan, melampaui batas dan ekstrem dalam segala urusan adalah terlarang dalam syariat. Hal ini tampak bahwa orang-orang Yahudi bersikap ekstrem terhadap Isa, hingga mereka juga melontarkan tuduhan palsu dan keji kepada sayyidah Maryam. Hal yang sama pula yang diyakini orang-orang nasrani berlebihan terhadap Isa hingga mereka menjadikannya sebagai Tuhan. Sikap semborono (al-Ifrat) dan sikap lalai (al-Taqsiri) dalam hal ini adalah jelek dan ingkar. ${ }^{37}$

Banyak ulama memahami ayat al-Nisā' [4]: 171 di atas hanya khusus ditujukan kepada orang-orang Nasrani tidak kepada orang Yahudi. Namun demikian menurut hemat M. Quraish larangan melampaui batas dalam mengamalkan agama tertuju kepada ahlul kitāb, yang telah melampau batas dalam keberagamaan mereka dan keyakianan mereka tentang Tuhan. Dimana mereka berkeyakinan bahwa Uzair putra Allah (lihat QS. Al-Taubah [9]: 30), mereka menjadikan rabbi-rabbi mereka sebagai tuhan-tuhan selain Allah SWT (lihat QS. Al-Taubah [9]: 31). Namun demikian pemahaman yang diambil oleh Quraish mengatakan secara tidak langsung dapat juga menjadi pelajaran bagi umat Nabi Muhammad SAW. Kata " $l \bar{a}$ taghlü" terambil dari kata "al-ghuluw," yakni melampaui batas yang dituntut oleh akal sehat atau tuntunan agama, baik dalam kepercayaan, ucapan, ataupun perbuatan. Ayat al-Nisā' [4]: 171 tersebut di atas, di samping menyebutkan gelar Isa as. Sebagai al-

\footnotetext{
${ }^{35}$ Ah̆mad Musțafā al-Marāghī,. Tafsīir al-Marāghī, Beirut: Dār al-Kutub 'Ilmiyyah, 1418 H/1998 M. Jilid. 4, hal. 26.

${ }^{36}$ Abi al Hasan Ali ibn Ahmmad al-Wahidi al-Naisaburi, Al-Wasit fí Tafsìr al-Majīd, Beirut: Dār al-Kutub al-Ilmiyyah, 1994, Jilid 2, hal. 142.

${ }^{37}$ Wahbbah al-Zuhaili, Tafsìr al-Wasit, penerjemah; Muhtadi et.al., Jakarta: Gema Insani, 2012, Jilid. 3, hal. 375-379.
} 
Masih, juga mneyebutkan nama beliau dana nama ibu beliau. Ini untuk menghilangkan kesalahpahaman yang mungkin timbul jika yang disebut hanya kata al Masih. Di sisi lain penyebutan nama ibu Isa as. untuk mengisyaratkan bahwa beliau adalah manusia yang diciptakan dan memiliki ibu sebagaimana manusia lain. ${ }^{38}$

Penjelasan yang sama pula disampaikan dalam tafsir Ibn Kathïr (701 H/ $1301 \mathrm{M}-774 \mathrm{H} / 1372 \mathrm{M})$ bahwa Allah SWT melarang Ahli Kitab bersikap ghuluw (berlebih lebihan) dan ifrät (melampaui batas dalam memberikan sanjungan). Hal ini banyak terjadi pada kaum Nasrani. Mereka melampaui batas dalam mengkultuskan Isa as, hingga mengangkatnya melebihi kedudukan yang diberikan oleh Allah SWT kepada beliau. Mereka mengalihkan posisi beliau sebagai Nabi menjadi sesembahan selain Allah, mereka menyembah Isa as. sebagaimana mereka menyembah Allah SWT Bahkan mereka berlebih-lebihan dalam menyikapi para pengikutnya (para rahib) yang dianggap sebagai orang yang berepegang kepada agamanya dan terpelihara dari kesesatan. Mereka mengikuti setiap apa yang mereka katakan, baik benar ataupun salah, sesat ataupun mengandung petunjuk, benar maupun dusta. Oleh karena itu Allah SWT berfirman dalam (QS. Al-Taubah; 31). ${ }^{39}$

Pada ayat itu pula yang dimulai dengan 'janganlah kamu melampaui batas dalam agamamu'. Kata 'melampaui batas' maknanya adalah keluar dari batas-batas hukum. Seperti dimaklumi bahwa segala sesuatu memiliki pertengahan dan dua ujung. Ketika seseorang memegang salah satu ujungnya, tentu akan berat sebelah kerena mengabaikan yang lain. Demikian juga kondisi pada ahli kitab yang telah terperangkap dalam sikap fanatisme. Mereka melihat suatu perkara dengan berat sebelah. Ahli kitab dari golongan Yahudi telah kufur kepada nabi Isa as. dengan menuduh ibunya (maryam)

\footnotetext{
${ }^{38}$ Ada tiga sifat yang disandangkan kepada Isa as. oleh ayat di atas. Yaitu 1). Sebagai rasul, 2). Kalimat Allah dan 3). Ruh dari Allah. Dalam ketiga hal ini orang-orang Nasrani melampaui batas. Yang menyatakan bahwa isa as. adalah anak Tuhan, yang terlahir dari kalimat Allah (kun fayakun), dan Isa as. juga yang bersumber dari Ruh qudus. Semua kekeliruan itu, diluruskan oleh ayat di atas dengan menegaskan bahwa Tuhan adalah wahid Maha Esa dalam Dzat, tidak terdiri dari unsur yang membentuk-Nya, karena jika demikian dia adalah Dzat yang membutuhkan bahagiannya, karena tanpa bagian itu ia tidak ada. Muhammad Quraish Shihab, Tafsir al-Mishbāh, Jakarta: Lentera Hati, Vol. 2, 2002, hal. 830.

${ }^{39}$ Abū al-Fidā' Ismail Ibn Kathīr, Tafsìr al-Qur'ān al- 'Azìm, ditahqiq oleh Abd alQādir al-Arnaūuţ, Riyād: Dār al-Salām, 1998, Jilid 1, hal.792-793.
} 
telah berbuat zina. Hal ini merupakan sikap keterlaluan dalam membenci sesuatu. Sedangkan pada sisi lain, kaum Nasrani berlebihan dalam mencintai nabi Isa as. hingga mereka berkata, "Dia adalah Tuhan atau anak Tuhan, atau bagian dari trinitas'. Allah SWTmenghimbau mereka untuk menyikapi agama dengan sikap pertengahan. $^{40}$

Secara eksplisit penjelasan dari para mufassir di atas menyatakan bahwa sejatinya Allah SWT melarang Ahli Kitab dari sikap berlebih-lebihan (ghuluw) dalam beragama, yaitu melampaui batas dan ketentuan yang disyariatkan kepada perkara yang tidak disyariatkan. Yang demikian sama halnya dengan prkataaan kaum Nasrani yang melapaui batas terhadap Isa dan penempatan mereka terhadapnya melebihi dari kedudukan kenabian dan kerasulan kepada kedudukan ketuhanan yang tidak patut diberikan selain hanya kepada Allah SWT Maka sebagaimana perkara asal-asalan dan lalai itu adalah perkara yang terlarang, maka disebut juga melampaui batas juga dilarang dalam agama. ${ }^{41}$

Sejalan apa yang dipaparkan di atas, berikut ayat sebagai mempertegas dan mempertajam akan larangan berlebih-lebihan dalam mengamalkan ajaran yang tidak dibenarkan dalam syariat, sebagimana termaktub dalam QS. Al-Māidah [5]: 77.

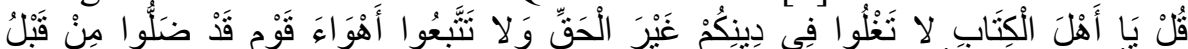

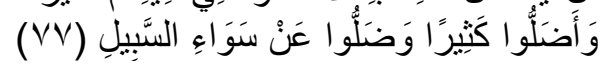

77. Katakanlah: "Hai ahli Kitab, janganlah kamu berlebih-lebihan (melampaui batas) dengan cara tidak benar dalam agamamu. dan janganlah kamu mengikuti hawa nafsu orang-orang yang telah sesat dahulunya (sebelum kedatangan Muhammad) dan mereka telah menyesatkan kebanyakan (manusia), dan mereka tersesat dari jalan yang lurus".

Pada kalimat "Qul yā ahl al-kitāb" (katakanlah hai ahli kitab) yang dimkasud adalah para pemeluk agama Yahudi dan Nasrani. "la taghluw" (janganlah kamu berlebih lebihan dan janganlah kamu melampaui batas) dalam agamamu secara berlebih-lebihan (dengan cara tidak benar). Yaitu dengan cara merendahkan nabi Isa as. atau

${ }^{40}$ Mutawalli al-Sha'rāwī, Tafsìir al-Sha'rāwī, Bairūt: Dār al-Ma'rifah, t.th. Jilid. 5, hal.2861.

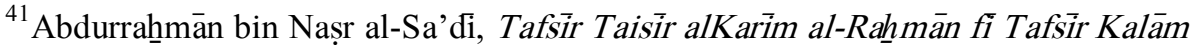
al Manān, ditahqiq Sa'ad bin Fawwāz Jeddah : Dār al-Madanì, Vol. 2. 1408 H/ 1988 M. hal. 216. 
kamu mengangkatnya secara berlebihan dari apa yang seharusnya. ${ }^{42}$ Quraish menjelaskan bahwa setelah jelas kesesatan dan kekeliruan orang Yahudi dan Nasrani, maka kedua kelompok ahli Kitab itu diingatkan agar tidak melapaui batas dalam beragama, termasuk melampaui batas dalam keyakinan tentang Isa as, dengan mempertuhankannya sebagaimana orang- orang Nasrani, atau menuduhnya anak haram sebagaimana orang Yahudi. Maka kata "taghluw" berlebihan digunakan juga dalam arti "melihat hakikat sesuatu dengan sungguh-sungguh, serta menganalisa yang tersembunyi dari satu teks. Oleh sebab itu dalam ayat di atas kata "ghair al-haq" dengan cara yang tidak benar. Dapat pula dikatakan bahwa kata 'ghair al-haq' bermakna 'yang tercela', dalam artian 'yang tidak dibenarkan', karena 'hak' adalah sesuatu yang terpuji, sehingga yang bukan hak adalah 'yang tercela'. Ini memberikan indikasi bahwa boleh jadi ada sesuatu yang berlebih tapi tidak tercela, seperti memuji suatu amal kebajikan.

Pada ayat itu pula disebutkan ada jenis dua kesesatan. Kesesatan pertama menyangkut kandungan tuntunan Nabi Musa as dan Isa al-Masih as, dan kesesatan kedua berkaitan dengan tuntutanan Nabi Muhammad SAW dan al-Qur'an. Dapat juga dipahami dari firman Allah 'ya ahlal kitab' dalam ayat itu sebagai ditujukan kepada orang-orang Nasrani saja, karena ayat ini ditempatkan sesudah kecaman kepada mereka, dan dengan demikian yang dimaksud dengan larangan ini adalah larangan kepada orang orang Nasrani agar tidak berlebihan dalam memandang Isa al-Masìh as. Terkait dengan ayat yang ditujukan kepada kaum Nasrani karena sudah melampaui batas batas agama. Kata "ghair al-haq" dalam pangkal ayat di atas dimaksud adalah sesuatu yang bertentangan dengan kebenaran agama sebagaimana yang telah ditetapkan. Maka dalam kelanjutan ayat di atas diiringi dengan larangan, "Janganlah kalian mengikuti hawa nafsu kaum yang sesat sebelum kamu" artinya, adalah para pendahulu mereka yang telah membuka peluang kesesatan terkait kesesatan yang dilakukan oleh Yahudi dan Nasrani. $^{43}$

\footnotetext{
${ }^{42}$ Ahnmad Musțafā al-Marāghì, Tafsìr al-Marāghī, Beirut: Dār al-Kutub 'Ilmiyyah, 1418 H/1998 M. Jilid, 4, hal. 170.

${ }^{43}$ Abi al Hasan Ali ibn Ahmad al-Wahidi al-Naisaburi, Al-Wasit fí Tafsìr al-Majīd, Beirut: Dār al-Kutb al-Ilmiyyah, 1994, Jilid 2, hal. 214.
} 
Setelah Allah SWT mematahkan dan meruntuhkan kebatilankebatilan umat Yahudi, kemudian mementahkan dan meruntuhkan kebatilan-kebatilan umat Nasrani, untuk selanjutnya memaparkan dalil dan bukti-bukti yang nyata yang tidak mungkin terbantahkan lagi tentang kebatilan, kesesatan dan kerusakannya. Maka Allah SWT, mengecam dan mengingkari setiap orang yang menyembah sesuatu selain Allah. Allah SWT, menegaskan bahwa semua sesembahan itu sama sekali tidak berhak terhadap sesuatu apapun dari ketuhanan. Kemudian Allah SWT berfirman yang ditujukan kepada seluruh kaum ahli kitab dari umat Yahudi dan Nasrani' wahai ahlul kitab, janganlah kalian melampaui batas secara tidak benar dalam agama kalian".

Dari ayat di atas menunjukkan bahwa sesungguhnya menyembah kepada selain Allah SWT membuktikan kandungan akal, dangkalnya pandangan, lemahnya pemikiran dan kegegabahan manusia. Karena kata "la-ma'büd" (sesembahan) adalah yang dimintai kemanfaatan dan ditakuti azabnya ketika teledor dan lalai terhadap-Nya, serta melanggar perintah-Nya. Setiap orang yang menyembah kepda selain Allah SWT, seperti menyembah bintangbintang, malaikat, berhala, arcaa para nabi para pemimpin dan tokoh ulung, walaupun manusia memiliki harapan bisa mendapatkan suatu kemanfaatan dari mereka serta menolak kemudratan dan keburukan melalui perantaraan mereka, maka semua itu adalah bentuk dari ilusi, degradasi fitrah manusia dan pengecohan terhadap logika dan pemikiran yang normal. ${ }^{44}$

Untuk itu kehati-hatian dalam memposisikan ritual manumbai yang berbau mistik, agar tidak terkategorikan dengan "melampaui batas" dan ketidakkewajaran dalam memperlakukan alam dengan ritual yang ada di masyarakat Petalangan. Karena itu pulalah, dalam ayat yang ternaktub pada QS. Al-Māidah [5]: 77, di atas dijelaskan bahwa ada kandungan peringatan agar umat Muhammad (Islam) tidak terjebak pada perangai dan karakter Yahudi dan Nasrani. Jangan sampai seorang muslim mengerjakan dosa dan maksiat serta keburukan seperti yang mereka lakukan, agar

\footnotetext{
${ }^{44}$ Wahbah al-Zuhaili, al-Tafsìr al-Munìr, Beirūt: Dār al-Fikr, 1991, Jilid. 5, hal. 276-279.
} 
umat Islam tidak mendapat bencana dan azab seperti apa yang telah menimpa mereka. ${ }^{45}$

Adapun maksud ayat di atas pula, kamu jangan melampaui batas kebenaran kepada kebatilan. Hal yang demikian sama dengan ucapan mereka tentang Isa as al-Masih yang telah disebut pada QS. Al-Nisā [4]: 177, juga seperti sikap mereka yang berlebiha lebihan pada sebagian tokoh tokohnya demi kecenderungan mengikuti hawa nafsu. Maka di akhir ayat di atas, terlihat 'bahwa mereka tersesat dari jalan yang lurus" artinya, jalan yang benar. Maka mereka mengumpulkan antara kesesatan dan menyesatkan (orang lain). Mereka itu adalah para imam kesesatan, dimana Allah memperingatkan umat Muhammad SAW., dari mereka dan dari mengikuti hawa nafsu mereka yang sesat dan pandangannya yang menyimpang. ${ }^{46}$

Allah SWT mengingkari siapa saja yang beribadah kepada selain-Nya berupa berhala dan tandingan-tandingan lainnya. Allah SWT menjelaskan bahwa semua itu tidak berhak sedikitpun untuk disembah. Maka dalam firman Allah SWT di atas ada kata kata 'qul' (katakanlah) ahli kitab janganlah kamu berlebih-lebihan”. Artinya janganlah melampaui batas dalam mengikuti kebenaran dan janganlah berlebihan terhadap orang yang kelalaian diperintahkan untuk memuliakannya. Janganlah kalian berlebihan sehingga kalian menganggapnya Tuhan, bukan Nabi. Sebagaimana yang kalian perbuat terhadap al-Masih. Ia hanyalah seorang Nabi, namun kalian mengangkatnya sebagai Tuhan selain Allah. Hal itu hanyalah terjadi karena kalian mengikuti tokoh yang sesat di masa dahulu. ${ }^{47}$

Secara ekplisit kata yang digunakan dalam ayat di atas adalah kata-kata "taghluw" atau "al-ghuluw" adalah satu sikap ekstrim dalam memberikan penilaian, baik yang bersifat postif maupun negatif. Yakni ekstrim dalam memuji ataupun mencela. Bila dilihat sepintas ayat di atas memiliki kemiripan dengan ayat QS. Al-Nisāa [4]: 171. Maka untuk mencari tahu bahwa masalah ekstrimitas

\footnotetext{
${ }^{45}$ Muhammad Ali al-Ṣāabunī, Ṣafwah al-Tafāsìr, Kairo: Dār al-Ṣābūnī, 1976, jilid. 3, hal. 78 .

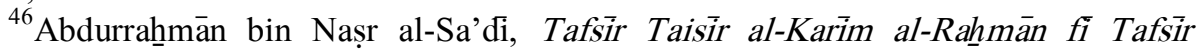
Kalām al Mannān, ditah̆qiq Sa'ad bin Fawwāz Jeddah : Dār al-Madanī, Jilid. 2. 1408 H/ 1988 M. hal. 241.

${ }^{47}$ Abū al-Fidā' Ismail Ibn Kathīr, Tafsìr al-Qur'ān al- 'Azìm, ditahqiq oleh Abd alQadir al-Arnaūţ, Riyād: Dār al-Salām, 1998, Jilid. 2, hal.113.
} 
terkait dengan klaim ketuhanan manusia, Allah SWT melanjutkan ayat "sesungguhnya al-Masih Isa as putra Maryam itu, adalah utusan Allah dan (yang diciptakan engan) kelimat-nya yang disampaikan Nya kepda Maryam, dan (dengan tiupan ) roh dari-Nya (QS. Al-Nisā' [4]: 171). Untuk itu tidak benar bersikap ekstrim hingga menuhankan Isa as. ataupun menjulukinya sebagai "Thālithu thaläthah/salah satu dari yang tiga. Jika kelahiran Isa al-Masih yang tanpa ayah meimbulkan keraguan dan menganggapnya sebagai suatu keajaiban, haruslah dipahami bahwa segala sesuatu terjadi hanya melalui kata "un fayakūn". Walaupun pada akhir ayat dinyatakan 'dan janganlah kamu mengikuti hawa nafsu orang orang yang telah sesat dahulunya". Kata 'ahwā hawa nafsu adalah sesuatu yang disenangi oleh nafsu yang kemudian dilarutkan dengan cara yang tidak dibenarkan. Maka setiap kata 'al-hawa' dalam al-Qur'an selalu ditujukan pada bidang kesesatan dan kerugian. ${ }^{48}$

\section{Rekonsiderasi Budaya Manumbai Masyarakat Petalangan}

Berdasarkan penjelasan para mufassir yang dihubungkan dengan peraktek perilaku manusia dalam hal ini yang dilakukan pada ritual manumbai menjadi sangat penting untuk diperhatikan keberadaannya dalam memosisikan antara suatu ritual dengan peraktek keagamaan dan pengamalan ajaran agama yang tidak boleh berseberangan dengan nilai-nilai yang dalam agama Islam itu sendiri. Pemborosan ritual lewat pengamalan mistik yang notabenenya bersebati dengan makhluk halus merupakan sesuatu yang harus dihindari. ${ }^{49}$ Sebab dikhawatirkan akan terjebak pada pengkultusan dan pemujaan yang serta-merta akan mendewakan apa yang menjadi objek dari upacara ritual tersebut. Untuk itu, kehati-hatian (ihtiyath) dalam prosesi ritual ini perlu dikedepankan. Sebab kalau tidak ritual ini dapat saja memberikan peluang dan membuka unsur kelalaian

\footnotetext{
${ }^{48}$ Mutawalli al-Sha'rāwī, Tafsìr al-Sha'rāwī, Baerūt: Dār al-Marifah, t.th. Jilid. 6. hal. 3317-3318.

${ }^{49}$ Dalam perspektif hukum Islam terhadap Magis terdapat beberapa istilah yang memiliki konotasi dengan perdukunan, kadang-kala istilah tersebut dipakai untuk makna yang sama, namun seringkali dipakai dalam makna berbeda. Istilah tersebut ialah: Kāhin (dukun), 'Arrāf (peramal), Rammal (tukang tenung), Munājim (ahli nujum), Sāhir (ahli sihir), dan hipnotis. Pemakaian istilah tersebut dalam makna yang sama disebabkan oleh kesamaannya dalam beberapa hal; Pertama: dari sisi pengakuan mengetahui hal-hal yang ghaib. Kedua: dalam sisi penerimaan informasi tentang hal yang ghaib tersebut dengan mempergunakan bantuan setan atau jin.
} 
dalam meminta kepada selain Allah SWT, dan terjebak kepada sisi kesyirikan.yang pada gilirannya melampaui proses penyampaian hajat atau keinginan seseorang kepada selain Allah SWT, lewat prosesi ritual manumbai.

Di dalam Islam, mempercayai kekuatan lain selain Allah secara tegas hukumnya adalah kufur dan termasuk perbuatan syirik. Kalau itu sudah sampai ketingkat keyakinan penuh bahwa keuatan yang dimiliki suatu benda mengalahkan kekuatan yang mutlak (Allah). Syirik di sini adalah mempersekutukan Allah SWT dengan selain-Nya, yaitu memuja-mujanya dan menyembah makhluk-Nya seperti pada batu besar, kayu, dan benda benda yang ditahbsikan lainnya. Syirik dikategorikan sebagai dosa paling besar yang tidak akan diampuni oleh Allah SWT. Allah SWT berfirman dalam alQur'an surat al-Nisā': [48]. Pada ayat lain dinyatakan bahwa perbuatan syirik adalah suatu kezaliman. Dalam al-Qur'an di sebutkan dalan QS. Lukman: [13]. Orang yang syirik diharamkan untuk masuk surga, sebagaimana firman Allah SWt dalam surat alMāidah: [72]. ${ }^{50}$

Kendatipun demikian, suatu hal positif dalam setiap kegiatan pada lingkup budaya manumbai pada Melayu Riau perlu juga diapresiasi mengutip pendapat UU. Hamidi.Bahwa acara manumbai juga mengandung arti sosial dari simbol bisa dilihat dalam berbagai kehidupan.Selain madu lebah sebagai benda menarik minat dalam persukuan Petalangan, namun madu lebah bagi masyarakat Petalangan tidaklah dapat dipandang sebagai milik juragan dengan beberapa pihak yang tampaknya mempunyai sangkut-paut dengan rimba kepungan sialang. Bagi mereka semua harta benda dan hak-hak

\footnotetext{
${ }^{50}$ Hadis Rasulullah SAW telah memperkuat untuk menperingatkan umatnya untuk tidak mendatangi dan mempercayai dukun ataupun membuka praktik perdukunan. Hadis yang berkenaan dengan hal tersebut: Pertama, larangan tentang mendatangi dukun, hal ini di tegaskan oleh Rasulullah SAW dalam sabdanya: Dari Mu'awiyah bin Hakam Radhiallahu 'anhu ia berkata kepada Rasulullah $S A W$ : ada beberapa hal yang biasa kami lakukan di masa jahiliyah, kami terbiasa datang ke dukun? Jawab Rasulullah SAW: "Jangan kalian datang ke dukun. Kedua, Larangan bertanya kepada dukun. Rasulullah SAW bersabda: "Diriwayatkan lagi oleh sebahagian istri Nabi $S A W$ dari Nabi $S A W$ : "Barangsiapa yang mendatangi tukang tenung untuk bertanya tentang sesuatu, maka tidak diterima darinya shalat selama empat puluh malam". Ketiga, larangan mempercayai Dukun. Dalam sebuah hadits rasul dijelaskan: Dari Abu Hurairah ra. bahwa Nabi $S A W$ bersabda: "Barangsiapa yang mendatangi dukun lalu mempercayainya, sungguh ia telah kafir dengan apa yang diturunkan kepada Muhammad $S A W^{“}$.
} 
perorangan berfungsi sosial, artinya hak-hak itu tidak boleh digunakan secara bebas menurut selera pemiliknya. Tiap penggunaan hak harus dibenarkan oleh fungsinya dalam golongan atau persukuan. Karena itulah hasil madu sialang itu telah dibagi bagi sesuai dengan fungsi hak tersebut dalam pesukuan di daerah itu. ${ }^{51}$

Terlepas dari itu semua, sesungguhnya Islam telah memberikan jalan keluar dari persoalan yang dapat menjerembabkan pemeluknya pada ghuluw atau berlebihan dalam mengamalkan ritual tertentu. $^{52}$ Dari sini pula seseorang secara pribadi atau kelompok secara kolektif untuk tidak terjebak pada prilaku-prilaku dan praktek yang membuatnya mengkultuskan objek ritual yang ada dari meminta dan tidak bermohon kepada Allah SWT., walaupun yang dijadikan objek tersebut tidak semata-mata berhala dalam wujud nyata. Namun lewat media suatu benda pun terkadang akan memberi pengaruh kepada minside pelakunya secara lambat-laun mengkhawatirkan akan mengeggerus pelakunya memberi keyakinan yang penuh akan kekuatan pada objek yang dijadikan prosesi ritual munumbai, yang selanjutnya juga akan mengusik kelalaian seseorang dalam memohon dari kepada sang pencipta Allah SWT, kepada keyakinan kekuatan semu pada objek yang lain seperti pada ritual manumbai.

Terkait dengan ada unsur kelalaian dalam proses peribadatan, Allah SWT mengingatkan dalam QS. Al-Ahqāf [46]: 5. Dalam ayat itu dimulai dengan pemaparan uraian yang merupakan bukti sangat

\footnotetext{
${ }^{51}$ Pembagian bisa dikategorikan atas dua cara. Pertama, apakah sialang itu merupakan kepunyaan (telah diserahkan mengelolanya oleh batin) suatu suku juragan termasuk ke dalam suku yang diberi hak mengelolanya. Kedua, apakah pihak juragan berada di luar suku yang mengelola sialang tersebut. Jika pihak jurgan muda dan tua terhitung di luar suku yang mengelola rimba kepungan sialang tersebut, maka pembagian untuk pihak mereka cukup besar. Ada kira kira 40 $\%$.selebihnya $40 \%$ lagi untuk semua anggota suku. Sedangka sisanya $20 \%$ lagi untuk kepala suku. (seperti batin dan pembesar adat lainnya) tukang sambut, dan para tamu yang dihormati. UU. Hamidy, Rimba Kepungan Sialang, Jakarta: Balai Pustaka, 1987, hal. 112.

${ }^{52}$ Aspek ghuluw (melampaui batas) ini, dapat saja terjadi bagi orang yang memperlakukan benda atau objek tertentu sebagai sesuatu yang memiliki kekuatan, yang dapat mendatangkan al-năfi' (manfaat) atau al-Ḍar (menolak mudarat). Kalau ini kemudian menjadi i'tiqad atau keyakinan bulat pada pelakunya, dimana benda tersebut dapat memberi manfa'at dan mendatangkan mudharat, maka dikhawatirkan kemudian akan terjebak pada perbuatan kesyirikan (mensekutukan Tuhan).
} 
jelas sambil membungkam dengan argementasi dan tuntunannya terhadap kesesatan kum musyrikin dalam penyembahan berhala. Maka ayat di atas menegaskan bahwa berhala-berhala yang mereka sembah, jangankan memiliki andil dalam penciptaan bumi atau langit, jangankan itu, memiliki sedikit pengetahuan pun berhala berhala tersebut kosong darinya. Ayat di atas menyifati sembahansembahan kaum musyrikin dengan sifat lalai yang merupakan sifat makhluk berakal.Hal tersebut karena sebagian dari sembahansembahan itu boleh jadi manusia atau malaikat. Di sisi lain, kalau yang dimaksud dengan sembahan-sembahan itu adalah berhalaberhala, maka penyifatan tersebut betujuan mengecam kaum musyrikin yang menyembah sesuatu yang tidak berakal, tetapi memperlakukannya sebagai berakal. Quraish Shihab mengatakan bahwa ada juga ulama yang memahami kata ghäfilūn adalah kaum musyrikin, yakni meski berhala mereka tidak dapat mendengar permohonan mereka, namun mereka tetap lalai dan tidak sadar. Juga beliau mengutip pendapat Tabâ'thabâ'î bahwa menjadikan penyifatan berhala-berhala dengan sifat makhluk yang memiliki rasa sebagai salah satu bukti adanya kehidupan dan rasa dengan segala sesuatu, walau benda-benda tak bernyawa. Kehiduapan dan rasa itu yang kini dalam kehidupan dunia tidak rasakan kehidupannya, akibat tidak tampak darinya tanda-tanda kehidupan. Namun di akhirat nanti akan terlihat dengan jelas tanda-tanda kehidupan itu. ${ }^{53}$

Ibn Kathir menerangkan berkenaan dengan ayat yang disinggung di atas bahwa pada ayat tersebut dijelaskan dengan gamblang sesungguhnya tidak ada seorang pun yang lebih sesat daripada orang yang menyembah barhala-berhala, meminta pada berhala-berhala itu apa yang tidak bisa dikerjakan sampai pada hari kiamat. Berhala-berhala itu lalai dari apa yang diucapkan kepadanya. Mereka tidak bisa mendengar, tidak bisa melihat, tidak pula bisa menghukum. Sebab berhala-berhala itu adalah benda mati dan batu tuli. $^{54}$ Dari penjelasan ini yang diterangkan oleh Ibn katsir di atas, berkenaan dengan dengan objek pada prosesi manumbai tersebut adalah pohon kayu yang dianggap sebagai pemilik atau penghuni pohon yang isinya madu, adalah merupakan suatu kelalaian dalam

\footnotetext{
${ }^{53}$ Muhammad Quraish Shihab, Tafsir al-Mishbāh, Jakarta: Lentera Hati, Vol. 13, 2002, hal. 74-75.

${ }^{54}$ Abū Ja'far Muhammad bin Jarìr al-Ṭabarì, Jāmi'al-Bayān fî̀ Tafsìr Āyi al-Qur'ān, Beirūt: Dār al-Fikr, 1988, Jilid 3, Jilid. 4, hal. 197.
} 
mengadakan ritual yang digelar pada masyarakat petalangan, kendatipun objeknya tidak disebut sebagai berhala sembahan.

Allah SWT membantah bersekutunya patung-patung dalam menciptakan bumi dan langit dengan mengatakan bahwa mereka tidak kuasa melakukan hal itu, maka dilanjutkanlah dengan menyatakan bahwa sesembahan-sesembahan itu pun tidak mengerti tentang ibadah dengan melanjutkan firman di atas. Tidak ada orang yang lebih sesat daripada orang yang menyembah patung-patung selain Allah, dan menganggapnya sebagai Tuhan. Padahal patungpatung itu apabila disembah maka mereka tidak mendengar dan tidak dapat menjawab sampai hari kiamat. Maksudnya mereka sama sekali tidak dapat memberikan jawaban selagi mereka berada di dunia. Karena patung-patung itu memang lalai terhadap penyembahan orang-orang musyrik, karena mereka memang batu, yang bisu dan tuli, dan tidak dapat mendengarkan dan tidak dapat pula berbicara. ${ }^{55}$

Senanda dengan penjelasan di atas yang menyatakan bahwa benda mati tidaklah dapat dijadikan objek dari suatu proses sembahan yang memungkinkan pelakunya dikategorisasikan dengan kelalaian dalam meminta lewat ritual yang sudah membudaya pada masyarakat petalangan. Untuk itu Wahbah Zuhaili menerangkan bahwa Ayat di atas dimulai dengan penegasan Allah SWT bahwa berhala-berhala yang disembah kaum musyrikin tidak memiliki kuasa apa-pun baik menciptakan maupun yang lainnya. Selanjutnya Allah mengiringinya dengan ayat di atas. Bermakna bahwa berhalaberhala sama sekali tidak berkausa atas apapun dan tidak memiliki pengetahuan tentang apapun. Sebab mereka hanyalah benda mati. Penyembahan kepada benda mati adalah kesesatan yang sesesatsesatnya. Sikap seperti ini tentu mengundang kecaman dan sindiran tajam. Tampak pada ayat (ilā yaum al-qiyāmah) adalah ungkapan alta'bid (selama-lamnya) berdasarkan ungkapan yang biasa digunakan oleh orang Arab. Allah SWT kemudian menegaskan bahwa berhalaberhala tersebut tidak mengetahui penyembahan yang dilakukan oleh manusia kepadanya. Ayat di atas senada dengan QS. Maryam [19] 81-82, dan QS. al-Ankabūt [29]: $25 .^{56}$

\footnotetext{
${ }^{55}$ Ahmad Musțafā al-Marāghì,. Tafsìr al-Marāghì, Beirut: Dār al-Kutub 'Ilmiyyah, 1418 H/1998 M. Jilid, 25-27. Hal. 7.

${ }^{56}$ Wahbah al-Zuhaili, al-Tafsir al-Munïr, Beirūt: Dār al-Fikr, 1991, Vol. 25-26, hal. 10-11.
} 
Dari penjelasan di atas yang mengadung anjuran bahwa meminta atau beradap tasi dengan sutau benda jangan sampai benda yang dijadikan objek suatu perbuatan memilki kuasa dan penguasaan yang berlebihan, sebab dalam ayat ini Allah menerangkan bahwa orang-orang musyrik yang menyembah berhala tanpa alasan yang benar itu adalah orang-orang yang sesat karena mereka menyembah sesuatu yang tidak dapat berbuat, melihat, mendengar, apalagi memperkenankan doa orang-orang berdoa kepadanya. Hal ini tidak dapat dilakukannnya di dunia, dan di akhirat tentu lebih tidak dapat dilakukannya. Berhala berhala itu sebenarnya adalah batu abut mati atau kayu yang dipahat oleh manusia sendiri. Oleh karena itu, mereka tidak dapat mendengar, memahami dan memperhatikan orang-orang yang berdoa kepadanya. Orang-orang yang benar adalah orang yang menganut akidah yang benar, yaitu akidah tauhid yang membawa manusia menyembah hanya kepada Allah. Tuhan YME, maha pencipta maha menentukan segala sesuatu yang membimbing menusia ke jalan kebahagiaan di dunia dan di akhirat. ${ }^{57}$

Maka untuk mempertegas kedudukan mengenai apa yang dilakukan pada proses manumbai adalah menilik pada QS. Hūd [11]: 123.

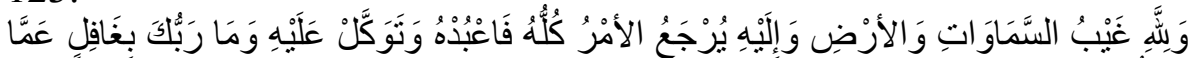

123. dan kepunyaan Allah-lah apa yang ghaib di langit dan di bumi dan kepada-Nya-lah dikembalikan urusan-urusan semuanya, Maka sembahlah Dia, dan bertawakkallah kepada-Nya. dan sekali-kali Tuhanmu tidak lalai dari apa yang kamu kerjakan.

Manusia tidak mengetahui yang gaib. Namun Allah SWT sebaliknya. Allah SWT menyaksikan perbuatan manusia yang gaib dan yang nyata, kerana kepunyaan Allah yang ada di langit dan di bumi. Dalam ayat di atas 'sembahlah dia dan bertawakkallah kepadaNya". Mengandung perintah menaati Allah SWT. Melalui melaksanakan perintah-perintahnya sesuai dengan kemampuan dan menjahui lerangannya. Hal itu agar yang bersangkutan memperoleh bantuan ilahi dalam melaksankan kegaiatan baru setelah setiap ibadah yang dilakukannya. Dengan demikian, melalui ibadah manusia akan memperoleh bantuan-Nya. Karena itu manusia seorang muslim diajarkan oleh surat al-fâtihah untuk mengucapkan ayat yang

${ }^{57}$ Tafsir Kementerian Agama RI, Al-Quran dan Tafsirnya (edisi yang disempurnakan) Jakarta : Kemenag RI, 2010, JUZ 26, hal. 245. 
ke lima dari al-fâtihah. Sebesar kualitas ibadah dan pengabdian masnuia kepada Allah subhânahu wataâlâ, sebesar itu pula anugerah Allah SWT padanya. ${ }^{58}$

Sebab Allah SWT maha tahu segala yang gaib di langit dan bumi. Hanya kepada-Nya lah tempat kembali segala sesuatu. Dia akan menghisab setiap orang yang melakukan perbuatan atas perbuatannya kelak pada hari kiamat. Kemudian Allah memerintahkan untuk beribadah dan bertawakkal kepadaNya semata. Karena sesungguhnya Allah maha mencukupi. Dia akan memberikan kecukupan bagi siapapun yang menggantungkan kepercayaan dan kembali kepadanya dalam segala urusan. Sebagaimana akhir dari ayat diatas "dan tuhanmu tidak akan lengah terhadap apa yang kamu kerjakan". Ini merupakan ancaman bagi orang-orang kafir pada waktu yang sama, ini sekaligus menjadi berita gembira dan penghibur hati bagi Rasulullah dan kaum mukminin. Sebab Allah SWT maha mengetahui segala sesuatu.Termasuk segala perbuatan orang-orang kafir yang mendustakan.Tanpa ada sedikit pun yang tersembunyi dari-Nya.

Dalam memahami masalah kegaiban dalam kehidupan adalah tidak sama. Ada hal yang ghaib mutlak tentu berbeda dengan hal-hal ghaib muqayyad yang memiliki pengantar, yang apabila diambil oleh manusia, maka akan terbukalah rahasia alam. Seluruh penemuan yang ghaib di alam ini memiliki waktu kelahiran yang dibuat oleh Allah SWT. Dalam firman Allah itu "dan kepadanyalah dikembalikan urusan-urusan semuanya”. Allah tidak berfirman "kepadanya kembali sesgala sesuatu". Karena Allah telah menentukan qadar bagi setiap makhluk. Dan pada akhir ayat di atas Allah SWT menyatakan "fa'bud watawakkal alaiahi wamā rabbuka bighāfilin ...". Maksudnya adalah patuhilah pada perintah Allah yang lebih tinggi darimu dengan cara melaksanakan tuntutan ibadah berupa shalat, zakat puasa dan haji, agar kamu mampu dapat mengambil bantuan darinya yang dapat menolongmu dalam kehiduapan ini. Suatu yang menakjubkan adalah bahwa aktivitas manusia dialam ini dibantu oleh yang lebih rendah dari manusia itu sendiri hingga dia dapat

\footnotetext{
${ }^{58}$ Muhammad Quraish Shihab, Tafsìr al-Mishbāh, Jakarta: Lentera Hati, Vol 5, 2002, hal. 793-794.

${ }^{59}$ Abū al-Fidā' Ismail Ibn Kathïr, Tafsìir al-Qur'ān al- 'Azīm, ditahquiq oleh Abd alQadir al-Arnaūţ, Riyād: Dār al-Salām, 1998, Jilid. 2, hal.113.
} 
mengambil bantuan kekuatan dari pencipta alam ini. Sa'rawi memberikan pendekatan pemahaman bahwa manusia akan membutuhkan seluruh ilmu kehidupan agar dapat melaksanakan shalat. Artinya, seseorang akan dapati dirinya dalam gerakan yang berputar di mana dia mengambil bantuan dari Allah SWT yang lebih tinggi untuk memberi pada alam yang lebih rendah dari dia. Lalu manusia mengambil dari yang lebih rendah sesuatu yang membuat dirinya dapat berdiri di hadapan pemberi bantuan tersebut. Perlu menjadi catatan bahwa seseorang akan mengalami kesulitan dan jika dia menemukannya, maka bertawakkalah kepada Allah SWT. Ini merupakan salah satu faedah dari istiqamah terhadap perintah Allah, yang kepada-Nya manusia memohon pertolongan. ${ }^{60}$

Untuk itu, berkenaan tentang kelalaian yang berkelanjutan seseorang tersebut mengutip pendapat Quraish Shihab menjelaskan bahwa redaksi dalam firman Allah SWT. Pada QS. Al-A'rāf [7]: 205 yang berakhir dengan, "Janganlah engkau termasuk kelompok orangorang yang lalai". Beliau menganalogikan bahwa seseorang yang masuk dalam kelompok tertentu, menunjukkan bahwa sifat, keahlian dan keterlibatannya dalam kegiatan yang ditekuni oleh kelompok tersebut amat mantap. Karena biasanya seseorang tidak dimasukkan dalam satu kelompok kecuali setelah memenuhi kreteria tertentu dan setelah melalui seleksi. Jika seseorang termasuk kelompok orangorang yang lalai, maka itu berarti kelalaiannya telah mencapai tahap yang sangat jauh. Ini berbeda dengan seseorang yang baru dinilai lalai. Penggunaan redaksi di atas memberi toleransi kepada setiap orang bila mana dalam perjalanan hidupnya terdapat kelalaian, selama kelalaiannya itu tidak berlarut. Karena itu pula al-A'rāf [7]: 205, berpesan agar memulai dan mengakhiri hari dengan mengingat Allah SWT. Jangan sampai lupa berzikir kepada-Nya. ${ }^{61}$

Dengan keterangan demi keterangan di atas, jelaslah bahwa ritual manumbai yang notabenenya melakukan ritual berupa pemanjatan doa berupa syair dan lirik lagu berupa pantun sebaiknya digunakan dengan ritual bernuansa islami lewat pembacaan doa permohonan kepada Allah SWT yang memiliki kuasa alam semesta, tanpa harus melibatkan kekuatan alam yang ada pada pohon atau

${ }^{60}$ Mutawalli al-Sha'rāwī, Tafsìr al-Sha'rāwī, Baerūt: Dār al-Marifah, t.th. jilid 11, hal. 6796-6802.

${ }^{61}$ Muhammad Quraish Shihab, Tafsìr al-Mishbāh, Jakarta: Lentera Hati, Vol 5, 2002, hal. 363. 
objek tertentu. $^{62}$ Sebab dalam agama Islam seseorang diperintahkan meminta lanngsung kepada Allah SWT, melalui perintahnya untuk berdoa sebagaimana terdapat pada QS. Al-Baqarah [2]: 186.

Maka dengan memberikan edukasi dalam memperkuat pondasi Islam yang kokoh dan pemahaman agama yang benar-lah yang kemudian secara berkala diharapkan dapat menggerus kepercayaan lama yang masih tersisa dari keyakinan kekuatan magis yang ada pada objek ritual tersebut, yang selanjutnya bisa dialihkan, menuju transformasi kepercayaan akan wujudnya permintaan yang fokus tertuju kepada Allah SWT semata yang memiliki kekuatan dan menguasai alam semesta melalui pembacaan ritual doa sebagaimana yang diajarkan dalam agama Islam.

\section{Epilog}

Masyarakat Melayu Riau yang berselogan "Melayu identik dengan Islam" slogan yang dimaksud terkesan dicederai dengan peraktek Manumbai atau tradisi menganmbil madu lebah masyarakat Petalangan. Lewat peraktek magis yang mengandung kekuatan batin, bertentahgan dengan larangan dalam al-Qur'an yang termakatub pada dalam QS. Al-Nisā' [4]: 171, yaitu 'al-ghuluw' bermakna melampaui batas dalam memperlakukan alam sebagai sesuatu objek memiliki kekuatan gaib dan dikhawatirkan terjerumus pada penyembahan kepada selain Allah Tuhan YME.

Penulis memberikan rekonsiderasi terhadap budaya manumbai masyarakat Petalangan Melayu Riau melalui transformasi. Lewat pemujaan terhadap pohon sialang yang diyakini memiliki kekuatan magis kepada kepercayaan pada keyakinan sepenuhnya kepada Allah YME yang maha pemberi dan penerima doa segala pinta hambanya. Seorang hamba diperintahkan meminta langsung kepada Allah SWT untuk berdoa, melalui perintahnya sebagaimana terdapat pada QS. Al-Baqarah [2]: 186. Perintah tersebut bertujuan agar seorang muslim tidak tergolong dalam

\footnotetext{
${ }^{62} \mathrm{Hal}$ ini pula yang kemudian di khawatrikan akan membawa pelakunya kepada ghuluw (melampaui batas), yang akan menyeret melakukan perbuatan "dibawah kesadaran" akal sehat. Ditambah lagi kalau itu diiringi dengan keyakinan bahwa benda tersebut dapat memberi manfa'at (an-nâfi') atau dapat menolak kemudratan (al-Ḍär). Kalau yang terakhir ini dilakukan maka sduah dipastikan pelakunya tergolong perbuatan kesyirikan (Musyrik).
} 
Rekonsiderasi Budaya Manumbai Masyarakat

Petalangan Melayu Riau Berbasis Al-Qur'an

kelompok sebagaimana dinyatakan dalam QS. Al-A'rāf [7]: 205 "orang-orang yang lalai".

\section{DAFTAR PUSTAKA}

Abādi, Majuddin Muhammad bin Ya'qūb al-Fairūz. al-Qāmūs alMuhịt, Beirut: Dār al-Jaìl, t.tp. Jilid 2.

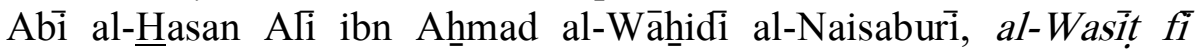
Tafsir al-Majīd, Beirut: Dār al-Kutub al-Ilmiyyah, Jilid 2, 1994.

Abror, Abd. Rachman. Pantun Melayu Titik Temu Islam dan Budaya Lokal Nusantara, (Yogyakarta: LKiS, 2009).

Aljunied, Khairudin Being Malay in Indonesia: Histories, Hopes and Citizenship in the Riau Archipelag, Social Analysis; Oxford Vol. 61, Iss. 3, (Autumn 2017).

Baqi', Muhammad Fuad 'Abdul. al-Mu'jam al-Mufahras li al-Fāz alQur'ān, Beirut: Dār al-Fikr, 1994.

Darmawi, Ahmad Bahasa dan Aksara Melayu Nusantara, (Pekanbaru: Dinas Pendidikan Provinsi Riau, 2010), V.

Dahlan, Ahmad Sejarah Melayu, (Jakarta: Kepustakaan Populer Gramedia, 2014).

Effendy, Tenas Tunjuk Ajar Melayu, (Pekanbaru: Dinas Pendidikan dan Kebudayaan Pemprov Riau, 2015).

--------, Tenas. Tunjuk Ajar Melayu, (Yogyakarta: Balai Kajian dan Pengembangan Budaya Melayu, 2011).

Grijns, C. Van der Tuuk and the study of Malay, In: Bijdragen tot de Taal-,Land- en Volkenkunde 152 (1996), no: 3, Leiden. 353381. Hamidy, UU. Sikap Orang Melayu terhadap Tradisinya di Riau, (Pekanbaru, Bumi Pustaka, 1991).

HAMKA, Tafsîr Al-Azhâr, Singapura: Pustaka Nasional PTE LTD, Cet kelima, 2003. Jilid 4.

Hussein, Ismail. Tamaddun Melayu Menyongsong Abad Kedua Puluh Satu, (Bangi: University Kebangsaan Malaysia, 2001).

Hasbillah, Ahmad 'Ubaydi. Ilmu Living Quran-Hadis : Ontologi, Efistemologi, dan Aksiologi, (Ciputat: Maktabah Darus Sunnah, 2019).

Hamidy, UU. Orang Melayu di Riau, (Pekanbaru: UIR Press, 1996), 133.

-------, UU. Rimba Kepungan Sialang, Jakarta: Balai Pustaka, 1987. 
-------, UU Kasin Niro Penyadap Enau Rantau kuantan, Pekanbaru: Puslit Universitas Riau, 1983.

-------, UU. Negeri Rantau, Pekanbaru : Bilik Kreatif, 2017.

Hanafi, Muchlis M. (ed), Tafsir Al-Qur'an Tematik, Amar Makruf Nahi Mungkar, (Jakarta: Lajnah Pentashihan Mushaf AlQur'an, 2013).

Imam Jalāluddin al-Mahallì dan Imam Jalāluddin al-Suyūṭ̂, Tafsìr Jalālain, (Beirut: Dār al-Kutub, 2002).

Al-Ishfahānī, Abū al-Qāsim Abū al-Husain bin Muhammad al-Rāgib. Al-Mufradāt fì Garīb al-Qur'ān, Mesir: Musțafà al-Bāb alHalabì, 1961.

Ishaq, Isjoni. et al., Orang Melayu Sejarah, Sistem, Norma dan Nilai Adat, (Pekanbaru: UNRI Press, 2010).

, Isjoni (ed), Antara Streotip dari Jati Diri Orang Melayu dalam "Orang Melayu" Sejarah, Norma dan Adat Istiadat" (Pekanbaru: UNRI Press, 2002).

Ibn Fāris, Abī al-Husein Aḥmad Ibn Zakariyā. Mu'jam Maqāyis alLughah, ditahqiq oleh Abd al-Salām Muhammad Hārūn, Beirut: Dār al-Fikr, t. th.

Junaidi, "Islam dan Kebudayaan dalam Tunjuk Ajar Melayu”, (Riau Pos, Ahad, 10 April 2011).

Kang, Yoonhee. Untaian Kata Leluhur, Marjinalitas, Emosi dan Kuasa Kata-Kata Magi di Kalangan Orang Petalangan Riau, diterjemahkan oleh Siti Rohana dari judul Words of the Ancestors, Words for Survival: Marginality Emotion and the Power Magical Words among the Petalangan of Riau, Pekanbaru: Gurindam Press, 2012.

Kathīr, Abū al-Fidā' Ismaìl Ibn. Tafsìr al-Qur'ān al-'Azìm, ditahqiq oleh Abd al-Qadir al-Arnaūţ, Riyād: Dār al-Salām, 1998, Jilid. 3.

MS, Suwardi. Dari Melayu ke Indonesia, Peranan Kebudayaan Melayu dalam Memperkokoh Identitas dan Jati diri Bangsa, Yogyakarta: Pustaka Pelajar, 2008.

Ma'luf, Louis. al-Munjīd fỉ al-Lughah wa A'lam, Beirut: Dār-alMashriq, 1976.

Al-Marāghī, Ahmad Mustafā. Tafsìr al-Marāghī, Beirut: Dār alKutub 'Ilmiyyah, Jilid. 4, 1418 H/1998 M.

Al-Marāghī, Ahmad Musțafā. Tafsìr al-Marāghī, Beirūt: Dār alKutub 'Ilmiyyah, 1418 H/1998 M. Jilid, 25-27. 
Marzūk, Abdul Șabūr. Mu'jam al-I'lām wa al-Mauḍu'āt fī al-Qur'an Munawwir, Ahmad Warson. Al-Munawwir Kamus Arab Indonesia, Surabaya: Pustaka Progresif, 1997.

Nurdin, Tengku Rizal. Pemberdayaan Masyarakat Melayu dalam Meningkatkan Pertahanan dan Ketahanan Nasional di Era Globalisasi, dalam Orang Melayu: Sejarah, Sistem, Norma dan Nilai Adat, (Isjoni, (ed), Pekanbaru: Unri Press, 2002), 78.

Quthb, Sayyid Fì Zilāl al-Qurān, Beirut: Dār Ihyā' al-Turāth al'Arabi, t.th. Jilid. 7.

Rahman, Elmustian. et, al. Ensiklopedi Kebudayaan Melayu Riau, Jilid IV. Pekanbaru: Pusat Penelitian Kebudayaan dan Kemasyarakatan Universitas Riau, 2012.

--------, Elmustian. et,al., Inventarisasi Kesusantraan Daerah Pelalawan, Pekanbaru: Dinas Kebuadayaan dan Kesenian dan Pariwisata, 2007.

Al-Sha'rāwīi, Mutawalli. Tafsìr al-Sha'rāwī. Berūt: Dār al-Marifah, t.th. Jilid. 5.

Al-Ṣābūni, Muhnammad Ali. Șafwah al Tafāsìr, Kairo: Dār al-Ṣābūnī, jilid. 1, 1976.

Al-Sa'di, Abdurrah̄mān bin Nașr. Tafsìr Taisīr al-Karìm al-Rah̆mān fï Tafsir Kalām al-Mannān, ditah̄qiq Sa'ad bin Fawwāz Jeddah: Dār al-Madanī, Vol. 2. 1408 H/ 1988 M.

Al-Sayyid, Abdul Hamid Mushṭafā. al-Af'āl fî̀ al-Qur'an al-Karìm, Ommān: Dār Wamaktabah al-Hamid, 2003, Juz 2.

Shihab, Muhammad Quraish. Tafsīir al-Mishbāh, Jakarta: Lentera Hati, Vol. 2, 2002.

M. Quraish. Menabur Pesan Ilahi, Al-Qur'an dan Dinamika Kehidupan Masyarakat, (Jakarta: Lentera Hati, 2006).

Suparlan, Parsudi Orang Sakai di Riau Masyarkat Terasing dalam Masyarakat Indonesia, (Jakarta: Yayasan Obor Indonesia, 1995), 50-51.

Suwarto, et.al., Mengangkat Keberadaan Hak-hak Tradisional Masyarakat Adat Rumpun Melayu se-Sumatera, (Pekanbaru: Unri Press, 2006).

Schauer, Matthew J. Custodians of Malay Heritage: Anthropology, Education, and Imperialism in British Malaya and the Netherlands Indies 1890-1939 University of Pennsylvania, Pro Quest Dissertations Publishing, 2012. 
Al-Ṭabarìi, Abū Jafar Muhammad bin Jarir. Jāmi'al-Bayān fíTafsìr Āyi al-Qur'ān, Beirūt: Dār al-Fikr, 1988, Jilid 3, Jilid. 4.

Tamrin, Husni. (ed), Agama dan Budaya, Pekanbaru: LPPM UIN Suska Riau, 2009.

Tafsir Kementerian Agama RI, Al-Quran dan Tafsirnya (edisi yang disempurnakan) Jakarta : Kemenag RI, 2010, JUZ 26.

Al-Zubaidi, Sayyid Muhammad Murtaḍ̄a al-Husaini. Tāj al- 'Urus min Jauhari al-Qāmūs, Beirut: Dār al-Ihyā al-Turāth al-'Arabī, 1987.

Al-Zuhaili, Wahbah. Tafsir al-Wasit, penerjemah; Muhtadi et.al., Jakarta: Gema Insani, Jilid. 3, 2012. 